Article

\title{
Eco-Innovation Diversity in a Circular Economy: Towards Circular Innovation Studies
}

\author{
Ana de Jesus ${ }^{1, *} \mathbb{B}$, Minna Lammi $^{2}$, Teresa Domenech ${ }^{3}$, Fedra Vanhuyse ${ }^{4}\left(\mathbb{D}\right.$ and Sandro Mendonça ${ }^{5,6,7}$ \\ 1 Center for Environmental and Sustainability Research, NOVA School of Science and Technology, \\ NOVA University Lisbon, 2825-149 Caparica, Portugal \\ 2 Lord Ashcroft International Business School, Anglia Ruskin University, Cambridge CB1 1PT, UK; \\ minna.lammi@aru.ac.uk \\ 3 Institute for Sustainable Resources, University College London, Gower St, Bloomsbury, \\ London WC1E 6BT, UK; t.domenech@ucl.ac.uk \\ 4 Head of the Societal Transitions Unit and Senior Research Fellow, Stockholm Environment Institute, \\ 11523 Stockholm, Sweden; fedra.vanhuyse@sei.org \\ 5 Business Research Unit (BRU-IUL), Instituto Universitário de Lisboa (ISCTE-IUL), 1649-026 Lisbon, Portugal; \\ sfm@iscte-iul.pt \\ 6 Research Unit on Complexity and Economics (UECE), ISEG-Lisbon School of Economics and Management, \\ 1249-078 Lisbon, Portugal \\ 7 SPRU—Science Policy Research Unit, University of Sussex, Brighton BN1 9RH, UK \\ * Correspondence: aij.silva@fct.unl.pt
}

Citation: de Jesus, A.; Lammi, M.;

Domenech, T.; Vanhuyse, F.;

Mendonça, S. Eco-Innovation Diversity in a Circular Economy: Towards Circular Innovation Studies. Sustainability 2021, 13, 10974. https:// doi.org/10.3390/su131910974

Academic Editor: Carlos Martin-Rios

Received: 17 August 2021

Accepted: 27 September 2021

Published: 2 October 2021

Publisher's Note: MDPI stays neutral with regard to jurisdictional claims in published maps and institutional affiliations.

Copyright: (c) 2021 by the authors. Licensee MDPI, Basel, Switzerland. This article is an open access article distributed under the terms and conditions of the Creative Commons Attribution (CC BY) license (https:// creativecommons.org/licenses/by/ $4.0 /)$.

\begin{abstract}
Transition to a Circular Economy (CE) is about structural change and is predicated on the introduction of transformative eco-innovation (EI). Research on the CE-EI nexus has recently attracted attention both from an analytical and regulatory perspective. However, in-depth research exploring EI dynamics within the CE is still marginal, especially concerning the trends and dynamics of the pro-CE innovation policy and strategy. This paper addresses this gap by taking advantage of the burgeoning research on CE of the last 20 years and offers a new working synthesis. By implementing a "(systematic) review of (systematic) reviews", this paper provides a new comprehensive framework for understanding pro-circular innovation strategies and, as a complement, argues the need to advance "circular innovation studies" as an agenda in its own right. Innovations related to recycling and recovery CE strategies along with business-model innovations and systemic/transformative innovations are found to be a major current trend in the research, connecting supply and demand side innovations and also driving other forms of innovation linked to design, product manufacturing, logistics and reverse logistics and end-of-life management and recovery. Additionally, of note is that the conceptual understanding of EI dynamics within a CE is still mainly implicit (rather than explicitly discussed) limiting the possibilities to advance knowledge in the area of innovation for CE: this is why we propose a "circular innovation studies" agenda.
\end{abstract}

Keywords: circular economy; innovation; systematic review

\section{Introduction}

The intense transformations resulting from the first Industrial Revolution and the deep political and economic changes after the 20th century World Wars have had an inescapable impact on the world. Technological progress has gone hand-in-hand with an exponential increase in the use of energy and resources, with more pollution, waste, biodiversity loss, and other harmful impacts [1,2]. How resources are extracted and usedand how goods are produced, consumed, distributed and disposed of-has become critical in managing a long-term sustained socio-economic development that is dependent on the environmental systems.

The emerging field of the Circular Economy (CE) has highlighted the risks associated with a predominant "take, make and dispose" techno-economic paradigm [3-5] and 
pointed the way towards a system that is regenerative, restorative and resilient by design [6]. Moving away from the notion of a linear economy (i.e., extraction, production, disposal), the CE advocates for rethinking how resources are used and cycled in an intentionally and permanently regenerative system. Although the last decade witnessed a rise of scientific output on CE [7], refinement of its core principles is still unfinished business [8]. This has led to claims of "label proliferation" on what "circular" really is, possibly hindering progress in the field and emptying " $\mathrm{CE}$ " of meaning $[9,10]$. This evolving debate has been addressed from a variety of perspectives [3,4,11]. Regardless, CE can be defined as a "regenerative system in which resource input and waste, emission, and energy leakage are minimised by slowing, closing, and narrowing material and energy loops. This can be achieved through long-lasting design, maintenance, repair, reuse, remanufacturing, refurbishing, and recycling" [4] (p. 759). Across sectors, there has been an increased awareness and emergence of policies to address minimisation of impacts and transition towards the $\mathrm{CE}$, such as the built environment [12], the agro-food industry [13], manufacturing (e.g., [14]), plastics $[15,16]$, the fashion industry $[17,18]$, and the management of different types of waste-from electronics [19-21] to food [22,23] and services [24,25]. Beliefs regarding CE's value in delivering sustainability have been divided between those skeptical of the concept and its meaning [26], and those persuaded of the potential that the approach is capable of realizing [27]. However, according to recent projections, CE operative models, together with climate mitigation measures, are necessary to support countries in meeting the Paris agreement of holding the Earth under the 1.5 degrees ceiling [28].

Innovation processes are at the core of societal transformations [29,30], and, as the CE entered the policy arena in the first decades of the 21st century (see, e.g., the EU's action plan for the CE [31]), it has become increasingly intertwined with the innovation agenda: $\mathrm{CE}$ has been considered dependent, at different levels, on the creation and launch of cleaner products, processes and business models, i.e., the introduction of transformative eco-innovations (EI) $[11,32,33]$. EI is also difficult to define given that the introduction of environmental/sustainability considerations into innovation studies has been permeated by several lexical variations. In the last decades, several terms have been used to connect innovation to environmental concerns, with interrelated, sometimes only slightly distinct, definitions, such as "Environmental innovation" [34-36], "Sustainable innovation" [37], or "Green innovation" [38-40], just to mention a few. At the same time, several frameworks to classify EI types and dimensions have also been proposed in the literature, ranging from the exploration of the EI determinants [41] to the analysis of the EI dimensions (design, user, product service, governance, etc.) [42], as well as degrees of effectiveness of EI [43], and EI indexes and indicators developed to support EI processes at different levels including sustainable development goals [44]. This definitional complexity is, by itself, an evolving agenda, and outside the scope of this paper. Nevertheless, the multitude of nuances makes the process of systemising EI dimensions and dynamics in the specific context of the $\mathrm{CE}$ difficult, needing a clear definition. Drawing on previous research, we adopt here the definition of EI as "new or improved socio-technical solutions that preserve resources, mitigate environmental degradation and/or allow recovery of value from substances already in use in the economy" [33], or, more specifically, as "any innovation that (a) has positive environmental impacts, and (b) directly or indirectly avoids natural capital damage, while delivering cost efficiencies, market enhancement, or regulation considerations, and (c) results in new or improved goods and services, technological and nontechnological processes, marketing or organisational schemes, (d) is incremental or radical, and (e) involves an actor or a plurality of actors" [11].

A "transformation turn" in how innovation is conceptualised (systemic, holistic and encompassing, not merely end-of-pipe competitiveness-driven tweaks) and its contribution to triggering a "deep transition" (a fundamental and sustained socio-technical realignment), this time towards circularity, is required [45,46]. In addition, existing research exploring EI dynamics within the $\mathrm{CE}$ is still marginal, especially concerning the trends and dynamics of the pro-CE innovation policy and strategy [47]. From a scholarly perspective, cross- 
fertilisation between the fields of innovation and CE is also largely absent. While the ever-growing body of the $\mathrm{CE}$ literature has tended to highlight the role of innovation, specific research which addresses CE innovation dynamics is lacking. Moreover, the exponential rise in $\mathrm{CE}$ contributions makes it even more difficult to have a synthetic, clear picture of circular innovation studies. To bridge this gap, this research undertakes a "review of reviews" to synthesize the most recent contributions on the CE-EI nexus, so as to shed some light on the dynamics, gaps and opportunities.

Through a systematic literature review, this paper places EI within a CE framework. We strive to chart and bring out the meaning of the most recent developments at the intersection of EI and CE, identify key gaps and areas of future work.

The research questions addressed are as follows:

- How has CE innovation research evolved since 2010?

- What is its distribution? (core academic outlets; core contributors, geographical dispersion, etc.)

- How are innovation dynamics conceptualised in CE research? How are types of innovation defined and unpacked?

Our paper contributes to the debate on innovation and circularity by extracting the major findings available in the extant "meta-research". That is, it maps the research advances brought about by the published reviews that are relevant to understand the interaction between EI and CE. As far as we know, this is the first effort made in that direction. This differs from traditional systematic reviews and is, at the same time justified by the very growth of the systematic literature, now in itself too abundant to apprehend. Our paper strives to identify prominent CE strategies where progress on EI has been made, and points to areas where future studies could best be directed attempting to encapsulate the major lessons learned, and derive some strategic implications. In so doing, we argue the need to advance "circular innovation studies" as an agenda in its own right.

This paper is structured as follows. Section 2 focuses on the methodological choices concerning the literature selection and corpus identification and covers definitional questions establishing the nexus between CE scope and key innovation patterns. Section 3 synthesises the results from the literature analysis. Section 4 discusses main outcomes, limitations and avenues for further research. Section 5 closes with some concluding remarks.

\section{Materials and Methods}

\subsection{Choice of Evidence Synthesis Method}

A systematic review can be characterised as a clear and replicable methodology focused on scoping, evaluating and synthesising evidence from a set of previous studies as to enable a set of qualitative and quantitative assessments on the evolution of a specific body of research [48-50]. This approach enables the study of the literature reflecting trends, weighting factors, recognising networks and identifying knowledge gaps.

Similarly to other systemic reviews [49,51,52], and to ensure consistency of the process, we develop a multi-step approach, including the following: (i) a clarification of the research questions (Section 1 of this paper); (ii) the establishment of an analytic framework to analyse the data (Section 2.2); (iii) the delimitation of the corpus according to a number of markers (Section 2.3,Section 2.4,Section 2.5,Section 2.6); (iv) a quantitative description of the evidence (Section 3); and (v) a synthesis of research results (Sections 4 and 5).

\subsection{Coding Scheme}

In the CE field, systematic reviews have been increasingly used to address con-ceptual questions related to definitional matters [9,51], sectoral specificities [53] and business setups [54-56], social aspects [57], as well as indicators and assessment techniques [58-60]. However, from an innovation perspective, contributions have been rather limited [11]. We hereby provide some coordinates into how the CE and EI have been understood and convert these lessons into a coding scheme. 
To classify CE approaches, we use the classification of Kalmykova et al. [27] who mapped a variety of existing approaches defining 45 implementation levels of CE strategies, aggregated by 9 stages of the value chain (Table 1). This taxonomy has the advantage of being empirically derived while retaining a conceptual focus.

Table 1. Strategies for implementing CE.

\begin{tabular}{|c|c|c|}
\hline \multicolumn{3}{|c|}{ CE Strategies } \\
\hline Value Chain Stage & Implementation Levels & Definition \\
\hline 1. Materials sourcing & $\begin{array}{ll}\text { - } & \text { Diversity and cross sector Linkages } \\
\text { - } & \text { Energy production/Energy autonomy } \\
\text { - } & \text { Green (public) procurement } \\
\text { - } & \text { Material assessment } \\
\text { - } & \text { Taxation } \\
\text { - Tax credits and subsidies }\end{array}$ & $\begin{array}{l}\text { CE Strategies focused on materials sourcing renewable } \\
\text { energy production as well as energy production from } \\
\text { by-products and/or residual wastes; material } \\
\text { substitution to renewable options; green procurement; } \\
\text { improved standardized method to better quantifies } \\
\text { environmental impacts; better taxation system not only } \\
\text { of inputs with negative externalities (aggravate) as well } \\
\text { as inputs with less environmental externalities (like } \\
\text { bio-based materials reducing). }\end{array}$ \\
\hline 2. Design & $\begin{array}{ll}\text { - } & \text { Customization/ built to order } \\
\text { - } & \text { Design for disassembly / recycling } \\
\text { - } & \text { Design for modularity } \\
\text { - } & \text { Eco-design } \\
& \text { Reduction }\end{array}$ & $\begin{array}{l}\text { CE Strategies focused on design to reduce harmful } \\
\text { substances use/waste/extended } \\
\text { life/disassembly/repair/refurbishment or recycling. } \\
\text { Focus is on design to limit environmental impacts during } \\
\text { the whole lifecycle. }\end{array}$ \\
\hline 3. Manufacturing & $\begin{array}{ll}- & \text { Energy efficiency } \\
- & \text { Material productivity } \\
- & \text { Reproducible and adaptable manufacturing }\end{array}$ & $\begin{array}{l}\text { CE Strategies focused on reduced material } \\
\text { input/consumption and energy efficient processes. }\end{array}$ \\
\hline 4. Distribution and sales & $\begin{array}{ll}\text { - } & \text { Optimizing packaging } \\
\text { - } & \text { Redistribute and resell }\end{array}$ & $\begin{array}{l}\text { CE Strategies focused on efficient packaging and } \\
\text { extended product life (like resale). }\end{array}$ \\
\hline 5. Consumption and use & $\begin{array}{ll}\text { - } & \text { Community involvement } \\
\text { - } & \text { Eco labelling } \\
\text { - } & \text { Product as a service/pay-per-use } \\
\text { - } & \text { Product labelling } \\
\text { - } & \text { Re-use } \\
\text { - } & \text { Sharing platforms } \\
\text { - } & \text { Stewardy responsible consumption } \\
\text { - } & \text { Virtualize }\end{array}$ & $\begin{array}{l}\text { CE Strategies focused on environmental } \\
\text { certification/labelling; new business models; } \\
\text { product-service-systems; sharing and } \\
\text { dematerialization models. }\end{array}$ \\
\hline 6. Collection and disposal & $\begin{array}{ll}\text { - } & \text { Extended producer Responsibility } \\
\text { - } & \text { Incentivized recycling } \\
\text { - } & \text { Logistics/infrastructure building } \\
\text { - } & \text { Teparation } \\
& \text { Take back and trade-in systems }\end{array}$ & $\begin{array}{l}\text { CE Strategies focused on take-back systems and } \\
\text { extended producer responsibility to a post-consumer } \\
\text { stage of a product's life cycle; as well as recycling, } \\
\text { namely enabling facilities to post-consumer optimum } \\
\text { separation, collection and disposal. }\end{array}$ \\
\hline 7. Recycling and recovery & $\begin{array}{ll}\text { - } & \text { Byproducts utilization } \\
\text { - } & \text { Cascading materials } \\
\text { - } & \text { Downcycling } \\
\text { - } & \text { Element/substance recovery } \\
\text { - } & \text { Energy recovery } \\
\text { - } & \text { Extraction of bio-chemicals } \\
\text { - } & \text { High quality recycling } \\
\text { - } & \text { Industrial symbiosis } \\
\text { - } & \text { Restoration } \\
\text { - } & \text { Upcycling } \\
\end{array}$ & $\begin{array}{l}\text { CE Strategies focused on using byproducts as raw } \\
\text { materials; cascading materials and components } \\
\text { (downcycling/upcycling). Element/substance/material } \\
\text { recovery; exchange and/or sharing of resources, services } \\
\text { and by-products between companies (e.g., } \\
\text { industrial symbiosis). }\end{array}$ \\
\hline 8. Remanufacture & $\begin{array}{ll} & \text { Refurbishment and remanufacture } \\
\text { - } & \text { Upgrading, maintenance and repair }\end{array}$ & $\begin{array}{l}\text { CE Strategies focused on maintenance/upgrading and } \\
\text { replacing components by reusable substitutes. }\end{array}$ \\
\hline 9. Circular inputs & - $\quad$ Bio-based materials & CE Strategies focused on regenerable inputs. \\
\hline
\end{tabular}

Source: Adapted from [27].

For EI, we built on, and adapted, de Jesus and Mendonça (2018), as it encompasses a broad scope of themes from more technological aspects to "non-technological" and "softer" aspects $[33,46]$ (Table 2). It also acknowledges that the nature of the change can range from incremental (i.e., introduction of small novel improvements, novel value in a specific context) to radical (disruptive change, completely new innovation) [61]. It 
accommodates not only the narrower conventional innovation types-product/service, process, organisational and marketing [62] — but also broader and holistic approaches where innovation is more than a single change but a socio-technical transformation, at a macro-level when talking about "systemic innovation" $[47,63,64]$, adding a new category to the micro-level when focusing on "business-model innovation" $[65,66]$.

Table 2. Aims and mechanisms of EI.

\begin{tabular}{|c|c|c|}
\hline \multicolumn{2}{|l|}{ Focus } & Key Types of Innovation (Targets) \\
\hline \multirow[t]{4}{*}{ Narrow Focus } & & $\begin{array}{l}\text { Organisational } \\
\text {-novel organisational method focused on improving organizational } \\
\text { structures in business/workplace organisation, learning processes, } \\
\text { institutional frameworks, etc. }\end{array}$ \\
\hline & & $\begin{array}{l}\text { Goods or services } \\
\text {-New product/Service. Tangible or intangible. }\end{array}$ \\
\hline & & $\begin{array}{l}\text { Process } \\
\text {-a novel or meaningfully improved production or delivery method }\end{array}$ \\
\hline & & $\begin{array}{l}\text { Marketing } \\
\text {-significant changes in product placement, product promotion or } \\
\text { pricing, sales and aftersales support }\end{array}$ \\
\hline \multirow[t]{2}{*}{ Holistic focus } & At a micro scale (business) & $\begin{array}{l}\text { Business-model innovation } \\
\text {-changes in an organization's value proposition and operating model. }\end{array}$ \\
\hline & At a macro scale (a city/country) & $\begin{array}{l}\text { "Systemic" innovation } \\
\text {-institutional changes at a sectoral and cross-sectoral, city and } \\
\text { trans-regional, national and cross-border levels }\end{array}$ \\
\hline \multicolumn{3}{|c|}{ Nature of the change (mechanisms) } \\
\hline \multicolumn{3}{|c|}{$\begin{array}{l}\text { Technological } \\
\text {-focus on technological innovation }\end{array}$} \\
\hline \multicolumn{3}{|c|}{$\begin{array}{l}\text { Nontechnological } \\
\text {-focus on nontechnological innovation }\end{array}$} \\
\hline \multicolumn{3}{|c|}{$\begin{array}{l}\text { Incremental } \\
\text {-gradual change or redesign of organisations, processes, products, sales, etc. }\end{array}$} \\
\hline \multicolumn{3}{|c|}{$\begin{array}{l}\text { Radical } \\
\text {-introduction of completely new innovations, "novel value" }\end{array}$} \\
\hline
\end{tabular}

Source: Based on $[11,61,67]$.

\subsection{Defining the Literature Corpus}

The literature searches were conducted in two of the world-leading databases of academic journals, Scopus and Web of Science (WoS) [68]. Scopus includes a larger number of journals [69], although it has a more "European focus" and a more limited chronological coverage [70]. WoS was the first bibliometric database coming into existence and still has a larger global coverage and covers a greater timeframe; however, it has a lower number of indexed journals [71]. The combined usage of both databases reduces potential limitations of each database, while other databases were excluded given resource constraints. For practical purposes, we only considered documents written in English.

\subsection{Data Collection, Screening and Quality Assurance}

Figure 1 summarises the data assemblage process. In a first step, we used the descriptor [circular* AND innovat ${ }^{*}$ ] and focused on the period 2010 to 2020 . After merging WoS and Scopus databases and a duplication check, a total of 2392 unique documents were identified. This query was, however, very broad (possibly including several not CE related documents), so a filtering was conducted, using the descriptor ["circular economy" and innovat* ${ }^{*}$. This second query (after merging WoS and Scopus databases and another duplication check) yielded 1173 documents. This second query had the advantage of 
providing a more focused dataset, but it may have potentially missed important articles from the first query. To avoid this limitation, we then proceed to compare the two queries. Overall, 1118 documents were found in both queries and were automatically accepted. The remaining papers (1274 from Query I and 55 from Query II) were screened on title and abstract for relevance (focus on CE, 1st round screening criteria) (Table 3). From those 1274, 170 were retained, making the new total therefore 1288 papers.
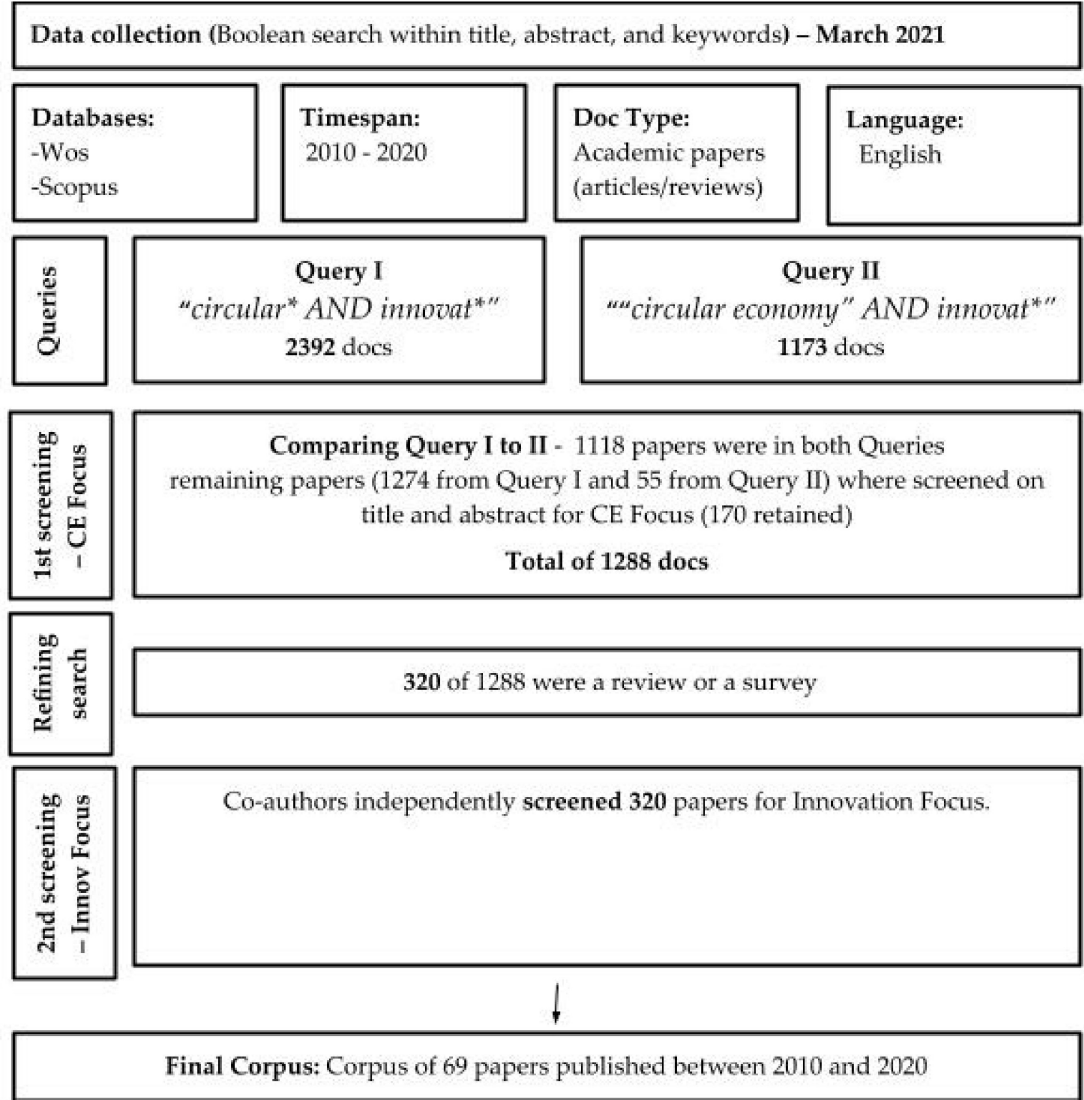

Figure 1. Data collection procedures. * was used to find wildcards in an exact word. For example, in "innovat" to find "innovation" as well as "innovating" or "innovator".

Given the size of the dataset, we crucially opted for a new angle of analysis, limiting the pool of papers to those aiming at synthesis, namely "reviews" or "surveys" (including systematic reviews, bibliometric reviews, scoping reviews, literature reviews, etc.) [72]. The use of a (systematic) review of (systematic) reviews has been used in other research areas (namely in health sciences) where there are also too many studies to analyse when making decisions or answering specific research questions [73]. The possibility to consider and synthesize existing studies in a single place has the benefit of allowing a deeper comparison of the findings of different reviews strengthening the evidence-based decision process [74]. The application of this perspective to our study was made considering that (i) there have been a proliferation of reviews and surveys concerning $\mathrm{CE}$ in the last years $[51,75]$ and (ii) that the role of a review paper is inherently a synthesis of the state of art in a specific subject, providing an essential step in the scientific process of knowledge accumulation [76,77]. One of the novelties of the present paper is, therefore, to be the most recent synthesis of the syntheses on the CE-EI intersection. Focusing on reviews and surveys, a total of 320 documents were retained for screening of relevance (1st and 2nd round screening criteria) (Table 3). A total of 251 articles were excluded in this round, resulting in a total of 69 papers relevant for our review. 
Table 3. Inclusion and exclusion criteria in the 1st and 2nd Screening.

\begin{tabular}{|c|c|c|}
\hline & Inclusion Criteria & Exclusion Criteria \\
\hline 1st Screening criteria & $\begin{array}{l}\text { Papers that presented at least one of the following focuses: } \\
\text { - } \quad \text { CE conceptual or theoretical definition } \\
\text { - } \quad \text { Empirical description or illustration of CE models } \\
\text { and applications at several levels (national, urban, } \\
\text { industry, etc) } \\
\text { - } \quad \text { Descriptive or normative perspectives on CE } \\
\text { challenges and future developments } \\
\text { - } \quad \text { CE policy developments and implications } \\
\quad \text { CE research gaps and future developments }\end{array}$ & $\begin{array}{l}\text { Papers that did not focus on CE: } \\
\begin{array}{l}\text { Definition } \\
\bigcirc \\
\text { Description } \\
\text { Or illustration }\end{array}\end{array}$ \\
\hline
\end{tabular}

Papers that focus on the conceptual and/or empirical definition/description/demonstration of one or more types on innovation within a CE approach namely:

2nd Screening Innovation Focus
- Technological innovation/Nontechnological

- Organizational innovation

- Product innovation

- Service innovation

- Process innovation

- Business-model innovation

- Disruptive innovation

- Radical innovation

- Design-driven innovation

- Social innovation

- Responsible innovation
Papers that do not:

- Analytically define

- Empirically/ Conceptually

characterise and or illustrate

- Measure any type of innovation as defined in the inclusion criteria

Source: Inspired by $[52,61,78]$.

\subsection{Quality Assurance}

Following systematic research guidelines and to ensure transparency, the deployment of numerous and recursive safeguards was a constant throughout the data harvesting and the screening process [79-81]. After each screening round, the main results and coding grid were revisited, and the inclusion of papers discussed focusing on those where there was uncertainty on relevance. A random subsample of $15 \%$ of the papers was analysed by the different authors in order to identify discrepancies in the analysis, ensure consistency of the coding system, compare results and reach consensus. This process pointed to a high level of agreement and consistency of the criteria applied by different reviewers.

\subsection{Analysis of the Full Texts}

Our final dataset of 69 articles was analysed on two levels: (i) a descriptive analysis focused on broad/ bibliometric trends (number of publications per year, authors, citations, etc.; (ii) a deeper content analysis focused on reflecting on innovation dynamics within, by linking circularity strategies with identified innovation patterns. Section 3 presents our findings.

\section{Results-Trends of the Pro-CE Innovation Research}

\subsection{Research Dynamics on the EI-CE Nexus}

Taking the number of publications as a (partial) measure of knowledge production, it is noticeable that the review articles focusing explicitly on innovation and CE are a recent strand of the literature, starting around in 2016. This finding converges with increasing policy and academic attention to the area of $\mathrm{CE}$ and coincides in time with the publication of the European Commission 2015 Circular Economy Action Plan where the role of EI is stressed: “(...) new technologies, processes, services and business models which will shape the future of our economy and society. Hence, support of research and innovation will be a major factor in encouraging the transition (...)" [31]. 
In the following years, the number of published papers grew steadily, reaching the highest number of reviewed publications (26) in 2020, that is, over a third of the articles in the sample (Figure 2). It should also be stressed that the number of papers in 2020 could be underestimated: on one hand, databases sometimes have delays updating information on the datasets; and on the other hand, 2020 was impacted by the Covid-19 crisis and consequent adjustments of academia to new conditions (digital classes, new conference formats, etc.) that may have affected publication efforts.

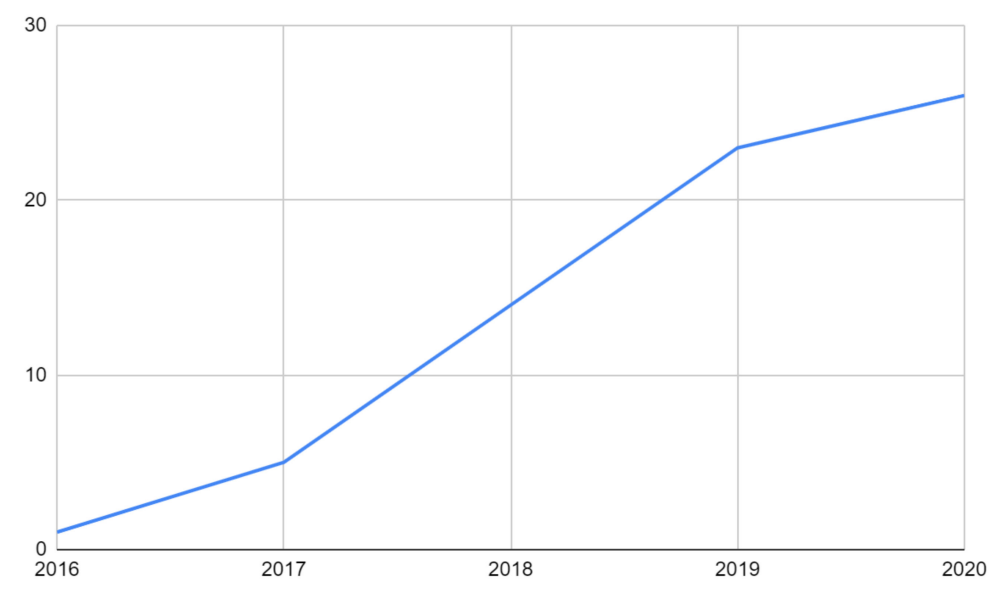

Figure 2. Number of papers per year on circularity and innovation. Source: elaborations on the corpus. Note: performance for later years can be underestimated, given to database updating.

The main outlets for this research are the Journal of Cleaner Production (16 papers), the Sustainability journal (9), followed by Ecological Economics (2), Management Decision (2) and Journal of Industrial Ecology (2) (Figure 3). Overall, the first two journals concentrate $36 \%$ of the sample papers, standing out as the major platforms for integrative/reflexive contributions that focus on the interaction between innovation and circularity. These core journals offer a transdisciplinary channel for "sustainability research and practice" (as described in the front-matter of the Journal of Cleaner Production) and "sustainability and sustainable development" (the Sustainability journal). The other journals range from ecological economics and industrial ecology to management as disciplines.

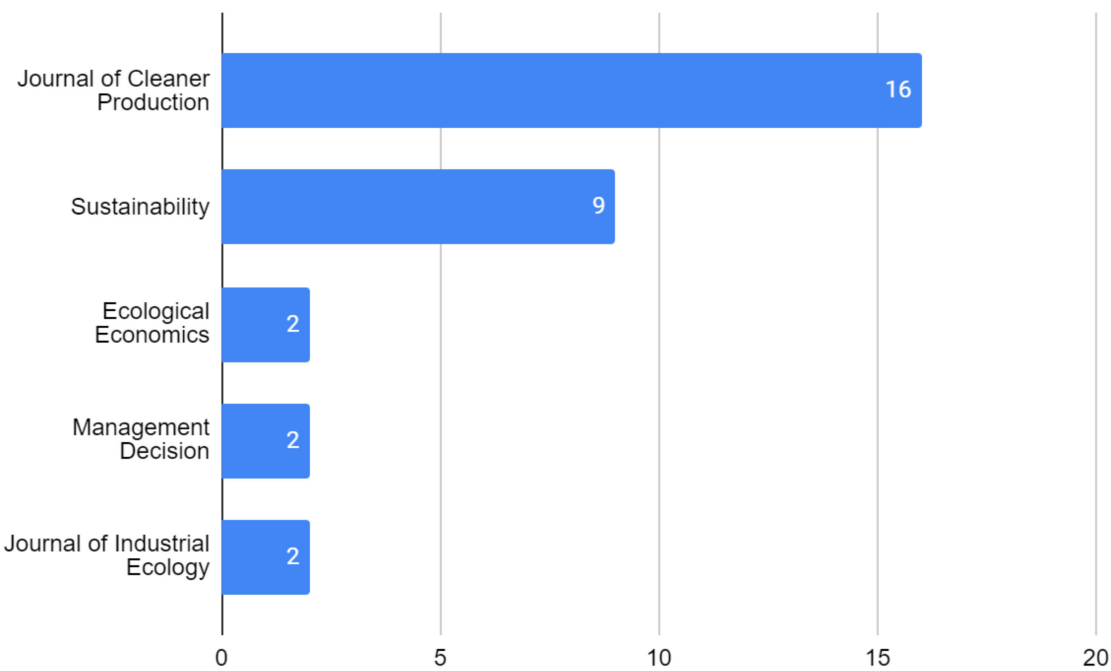

Figure 3. Number of papers per journal. Source: elaborations on the corpus. 


\subsection{Citations and Focus of Key Contributions}

The five most cited articles are mostly concerned with the conceptual definition of CE [82], the technological/nontechnological eco-innovation enables and hurdles for the transition [33,83], as well as the role of circular business-model innovation in the transformation $[66,83,84]$ (Table 4).

Table 4. Top five most cited documents.

\begin{tabular}{|c|c|c|c|c|c|}
\hline Title & Authors & Source Title & Date & Total Citations & $\begin{array}{l}\text { WOS Highly Cited } \\
\text { Papers/Academic Field }\end{array}$ \\
\hline $\begin{array}{l}\text { Towards a consensus on the } \\
\text { circular economy }\end{array}$ & $\begin{array}{l}\text { Prieto-Sandoval, V.; Jaca, C.; } \\
\text { Ormazabal, M. }\end{array}$ & $\begin{array}{l}\text { Journal of Cleaner } \\
\text { Production }\end{array}$ & 2018 & 168 & Engineering \\
\hline $\begin{array}{l}\text { Implementation of Circular } \\
\text { Economy Business Models by } \\
\text { Small and Medium-Sized } \\
\text { Enterprises (SMEs): Barriers } \\
\text { and Enablers }\end{array}$ & $\begin{array}{c}\text { Rizos, V.; Behrens, A.; van } \\
\text { der Gaast, W.; Hofman, E.; } \\
\text { Ioannou, A.; Kafyeke, T.; } \\
\text { Flamos, A.; Rinaldi, R.; } \\
\text { Papadelis, S.; } \\
\text { Hirschnitz-Garbers, M.; } \\
\text { Topi, C. }\end{array}$ & Sustainability & 2016 & 157 & Environmental/Ecology \\
\hline $\begin{array}{l}\text { Lost in Transition? Drivers } \\
\text { and Barriers in the } \\
\text { Eco-innovation Road to the } \\
\text { Circular Economy }\end{array}$ & de Jesus, A.; Mendonca, S. & Ecological Economics & 2018 & 127 & Economics/ Business \\
\hline $\begin{array}{l}\text { Sustainable business-model } \\
\text { innovation: A review }\end{array}$ & $\begin{array}{c}\text { Geissdoerfer, M.; } \\
\text { Vladimirova, D.; Evans, S. }\end{array}$ & $\begin{array}{l}\text { Journal of Cleaner } \\
\text { Production }\end{array}$ & 2018 & 124 & Engineering \\
\hline $\begin{array}{l}\text { Exploring Industry } 4.0 \\
\text { technologies to enable } \\
\text { circular economy practices in } \\
\text { a manufacturing context: A } \\
\text { business-model proposal }\end{array}$ & $\begin{array}{c}\text { Nascimento D.L.M., } \\
\text { Alencastro V., Quelhas } \\
\text { O.L.G., Caiado R.G.G., } \\
\text { Garza-Reyes J.A., Lona L.R., } \\
\text { Tortorella G. }\end{array}$ & $\begin{array}{l}\text { Journal of Manufacturing } \\
\text { Technology Management }\end{array}$ & 2019 & 104 & Engineering \\
\hline
\end{tabular}

The most influential papers are quite recent (from 2016 onwards), but all of them are considered "highly cited" in the WoS, meaning that those papers received enough citations to place them in the top $1 \%$ of a specific academic field [85]. These papers seem therefore to be informing further research, presumably on the linkage between EI and CE. The importance of the engineering academic field, when talking about CE and EI, is also put on evidence, even if papers on the Environmental/Ecology and Economics/Business fields were also "highly cited".

\subsection{Nature and Scope of the EI/CE Research}

A conceptual paper provides a structure to organize observations; a theoretical paper provides an explanation of a set of observed phenomena based on logical derivations; as for empirical papers, focus is on deriving predictions based on specific assumptions, usually using mathematical terms [86]. In the sample, the importance of conceptual contributions, or even purely theoretical papers, points to an ongoing debate of the interaction between $\mathrm{CE}$ and EI. However, more recent contributions show a growing focus on empirical studies as reflected in Figure 4.

In terms of scope, most of the sample reflects a global focus (with papers focusing on examples from different continents); however, its dispersion in terms of scope is quite uneven (Figure 5). Notwithstanding, it is also striking that for those articles in the sample that refer to a specific geographical region, the pattern is rather polarised: Europe is the area of choice; the visibility of the Global South is found wanting. 


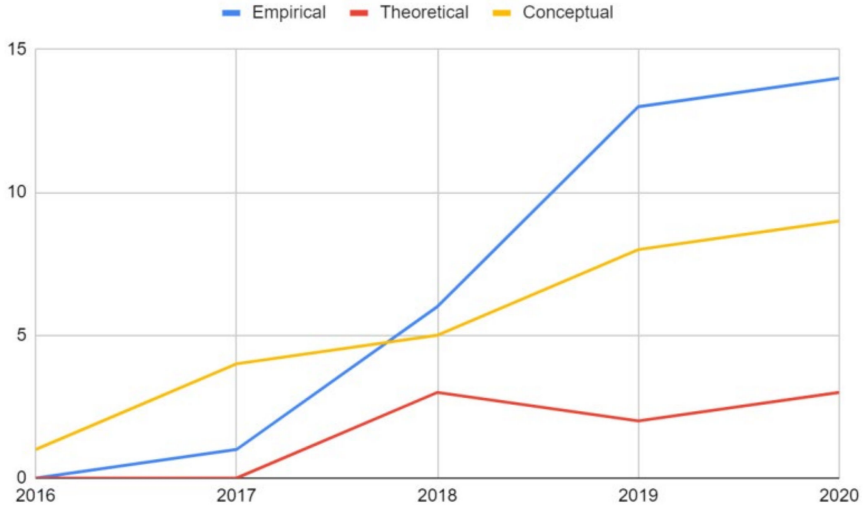

(a)

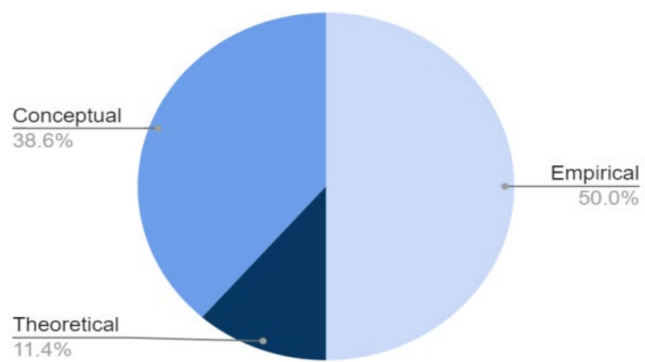

(b)

Figure 4. (a) Number of papers per year divided by nature of the research; (b) Overall \% of papers per nature of the research. Source: elaborations on the corpus.

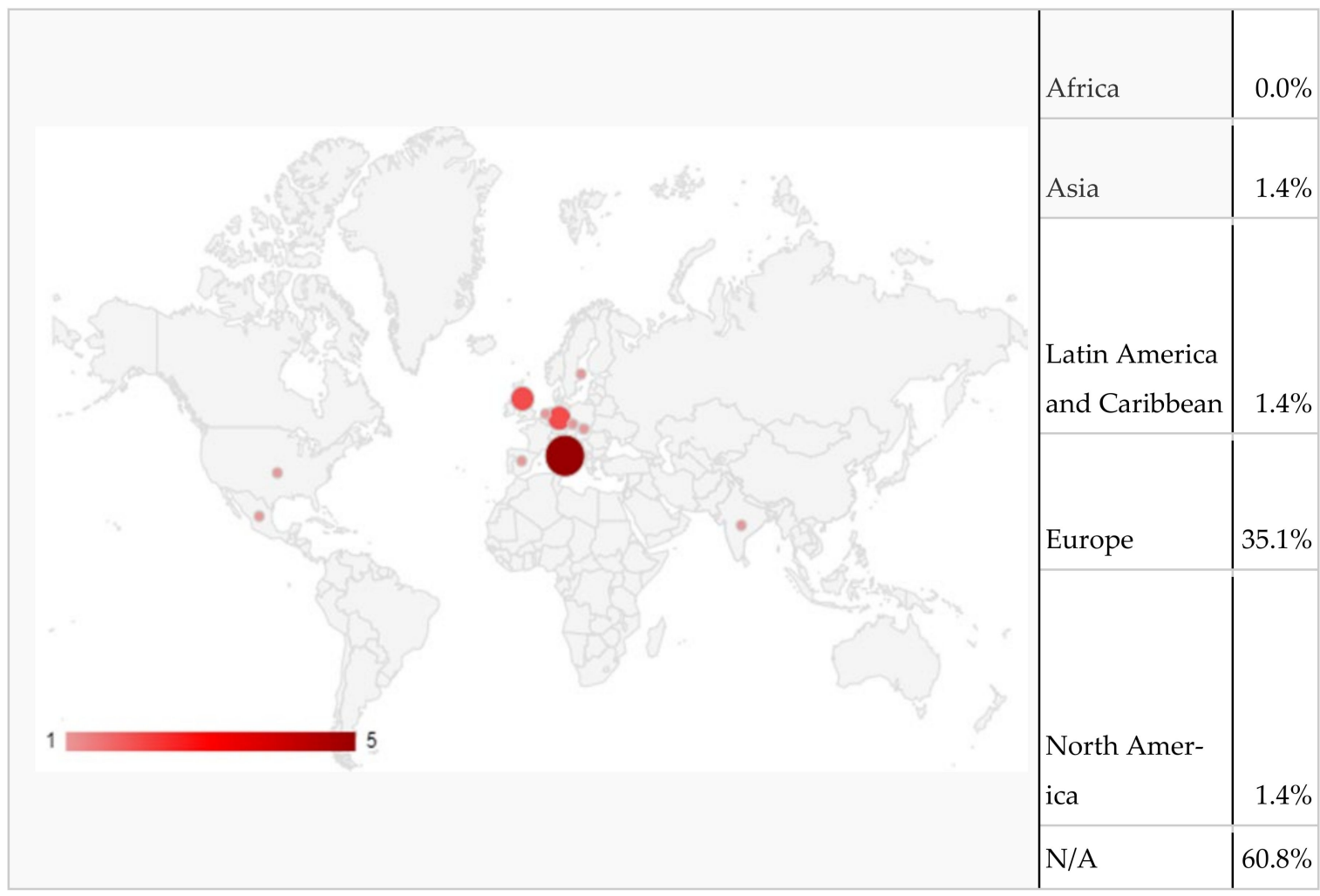

Figure 5. Geographical focus of the examples mentioned on the sample. Source: elaborations on the corpus.

A greater density of examples focusing on innovation within a CE are traceable to Europe. This agglomeration may be related to the large weight attributed to structural change and environmental performance in the priorities established in the CE 2015 Action Plan and related funding to research and development in the area [31] and historically the prominence of CE research in Europe. Reviews (in English) of the CE-EI literature is less apparent in other latitudes (e.g., Africa and the Americas) or nearly so (Asia). More than answers, these observations point to several other questions concerning the differences in understanding on CE and innovation concepts (Global North/South) as well as considerations on research impact of linking CE with a country's innovation agenda (an area where further research is needed). 


\subsection{Key Types of Innovation in CE: Main Dynamics of the Pro-CE Innovation Research Programme}

With regards to the way innovation dynamics is portrayed in the sample (In this section, as references originate directly from the corpus analysis, they have been grouped during the analytical process to reflect clusters of the literature addressing different $\mathrm{CE}$ 'strategies'.), there seems to be a focus on incremental progress, that is, the paced introduction of novel improvements/value in a specific context (rather than radical disruptive change) [61] within the bounds of a known technological trajectory (Figure 6). However, the split in the sample between technological focus (around 52\%) and nontechnological innovation $(47 \%)$ is remarkably even. The sample also suggests a predominance of research in the area of business-model innovation $(23.8 \%)$, with a focus on product/service packages (Figure 7).

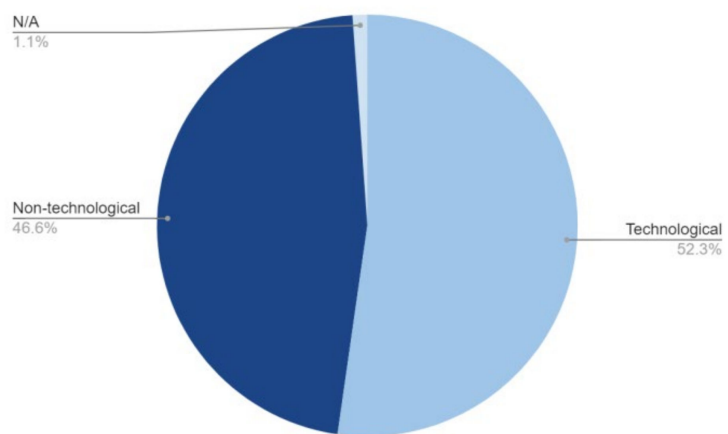

(a)

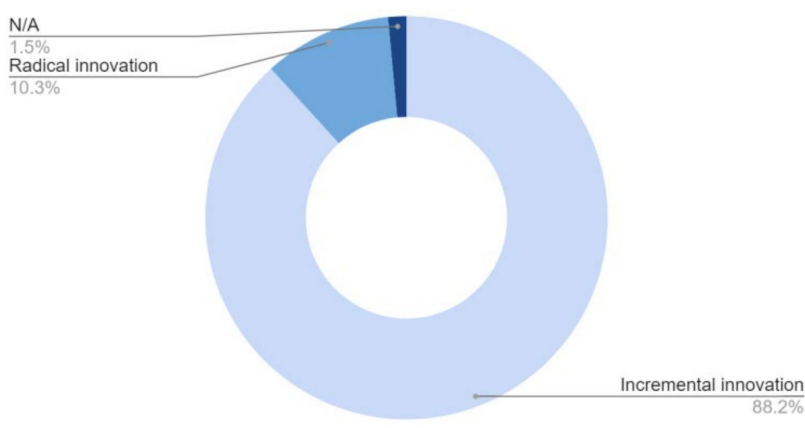

(b)

Figure 6. (a) Main innovation mechanisms in the corpus; (b) Main impact in the corpus. Source: elaborations on the corpus.

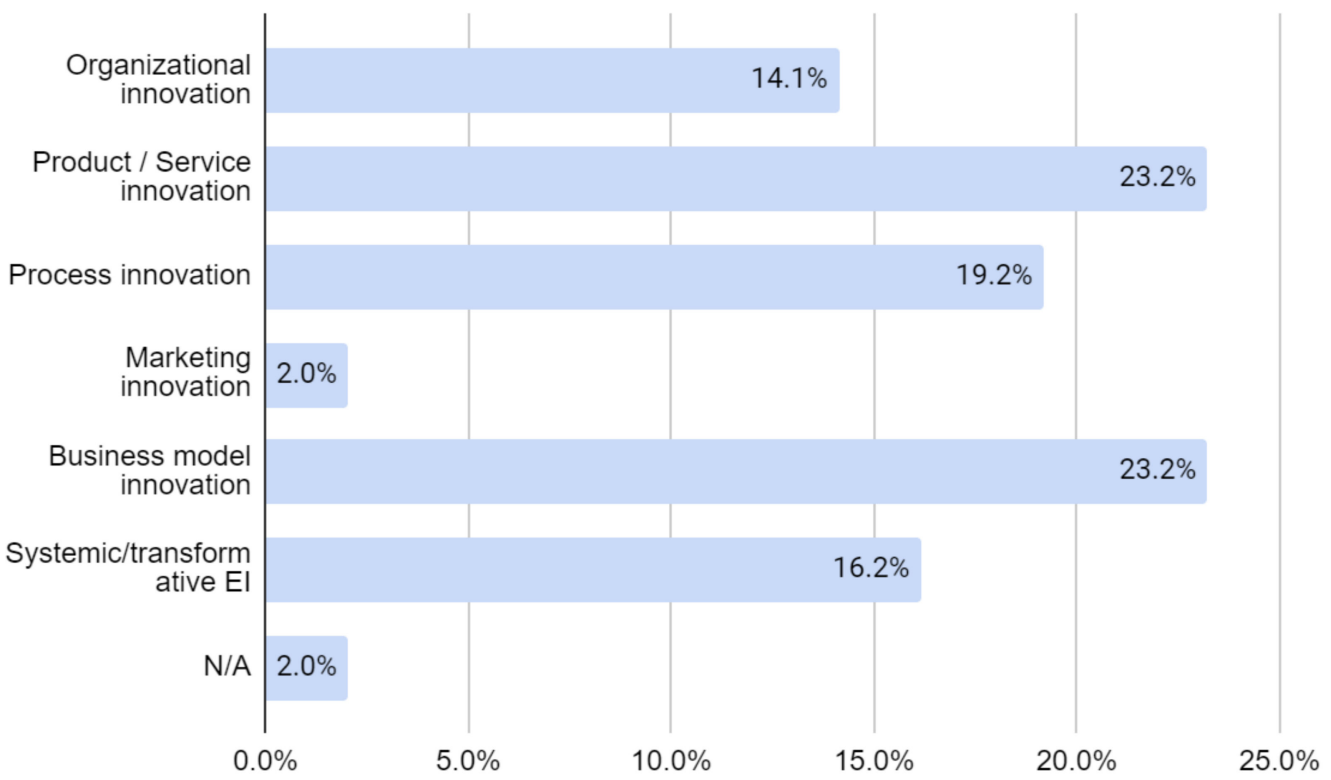

Figure 7. Main types of innovation in the corpus. Source: elaborations on the corpus.

We also classified the sample according to CE strategy areas. Two main CE strategies focused on "Recycling and recovery" (28\%) and "Consumption and use" $(21 \%)$ seem to be prevalent in the sample of papers, although a relatively large fraction of the sample (14\%) does not focus on specific CE strategies (designated as N/A-Not Applicable). Remaining strategies as proposed in the analytical framework include "Circular Inputs" (8\%); "Design" $(8 \%)$, "Collection and disposal" (5\%), "Remanufacture" (5\%), "Materials sourcing" (4\%), "Manufacturing" (4\%) and "Distribution and sales"(3\%) (Figure 8). 


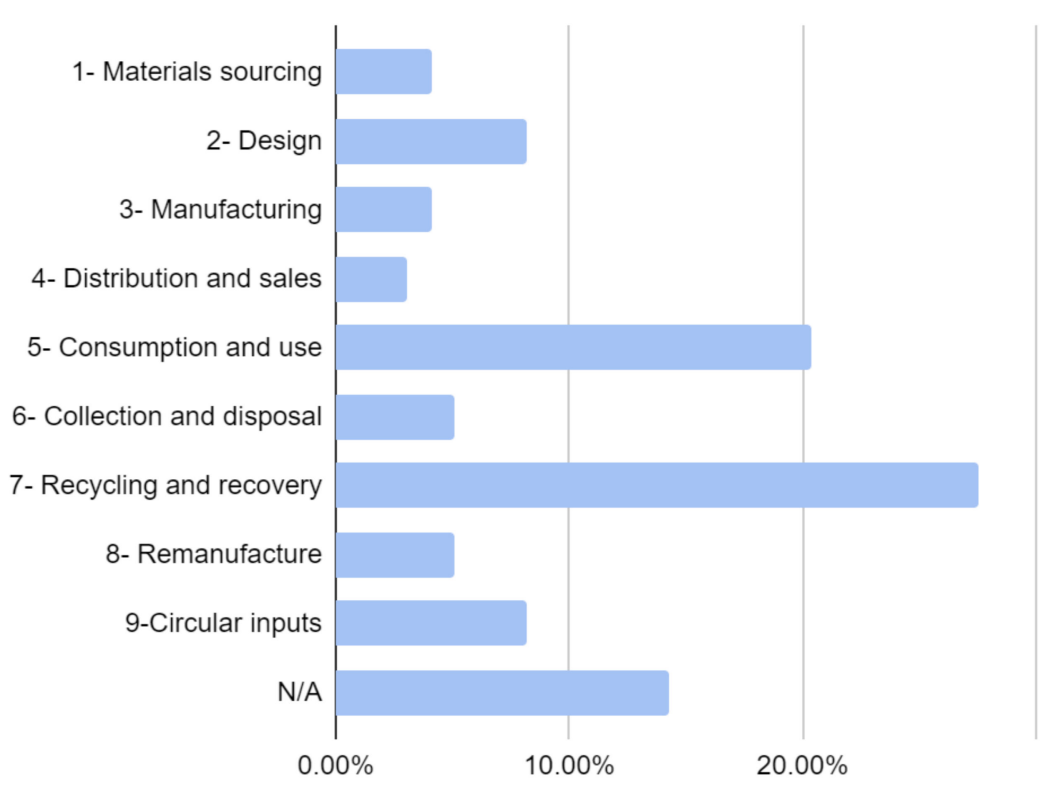

Figure 8. Main CE strategies (organised according to stages of the value chain). Source: elaborations on the corpus.

The next subsections review how innovation is considered within the two main CE strategies (Sections 3.4.1 and 3.4.2), discussing how an important part of the sample does not specifically align with any of the mentioned CE strategies (Section 3.4.3), and reflecting about remaining, less mentioned, CE strategies (Section 3.4.4).

\subsubsection{Recycling and Recovery-Rewiring Production}

The majority of papers from the sample are linked to strategies related to recycling and recovery. A set of papers focus specifically on the use of wastes and byproducts, namely in the agriculture, forestry and fishing sector [87-89]; the construction sector $[90,91]$ and the clothing/textile sector $[14,18]$.

Within this same strategy, another set of papers focus on technology and process innovations related to material composition and material recovery, with a focus on electric and electronic devices/metals and critical raw materials [92-94] as well as nutrient recovery from wastewater [95-98].

Another area addressed within this strategy is linked to industrial symbiosis, i.e., collaborations between companies focusing on sharing of services and byproducts is another subject approached $[99,100]$ where the emphasis is on inter-organisational innovation and networks.

In the $C E$ recycling and recovery strategies most papers in the sample focus on the technological side of the innovation process (Figure 9) which differs from overall findings where there is a more balanced split between technological and nontechnological innovations. Additionally, this group has a significant sectoral focus, but innovation dynamics tend not to be described in detail [18,98,99,101].

Overall, Recycling and recovery strategies are associated with product/service innovation, as well as technology and process innovation (Figure 9). Product/service innovation is linked with product recycling and end of life management [92,93]. The area of technology/process innovation relates more to recycling processes and technologies to upgrade or recover high-value-added marketable secondary materials [88,97]. Several papers stress the role of compliance and regulations in driving EI in CE recycling and recovery strategies $[88,90]$, while acknowledging that a solely regulatory focus is insufficient to move in the direction of a regenerative system [90]. 


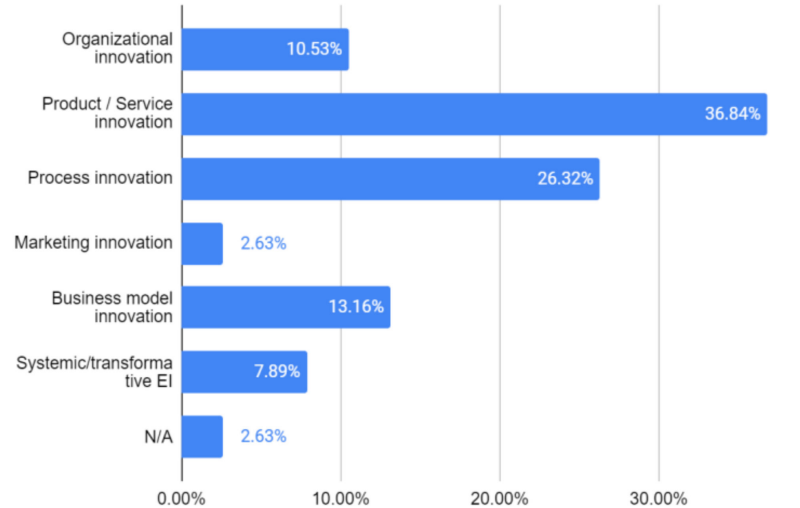

(a)

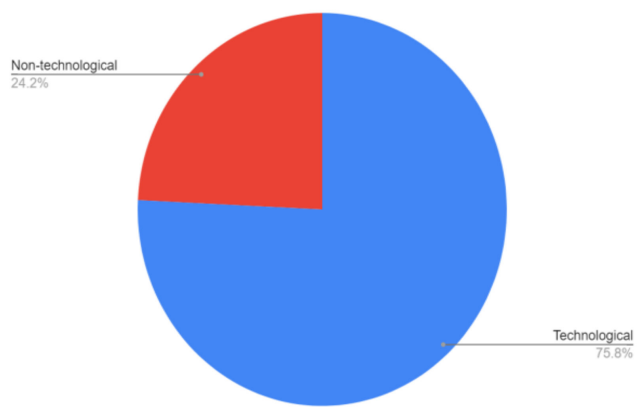

(b)

Figure 9. (a) Main types of innovation per "Recycling and recovery" CE strategy (value chain); (b) Main mechanisms of innovation per "Recycling and recovery" CE strategy (value chain). Source: elaborations on the corpus.

\subsubsection{Consumption and Use-New Business Models}

Around $21 \%$ of the sample address CE strategies related to "Consumption and use". Even if we use classification from Kalmykova et al. [27], examples on "Consumption and use" strategies in our sample are mainly focused on "New Business Models". The specific focus was on product-service-systems, i.e., shifting from a product-ownership-based to a function-based consumption [25,102,103], sharing and dematerialization models [83,104], and business-model innovations [54,66,84,105-109].

This subset of the sample is less sectoral driven and more focused on stakeholder perceptions and challenges and limitations for circular business models and business-model innovation for CE $[54,105,110]$. From a business organisation perspective, several papers mention firms' low awareness of the CE potential, considering it too costly and risky, especially SMEs [111]. On the user/demand side, user willingness to participate and/or adopt circular business models is also addressed, bridging the gap between supply/demand side innovation and stressing the need to engage stakeholders along the process of transformation [112-115]. In this area, research of a nontechnological nature prevails (Figure 10). Furthermore, the relevance of this topic suggests a growing research interest in the nexus between business models, innovation and CE.

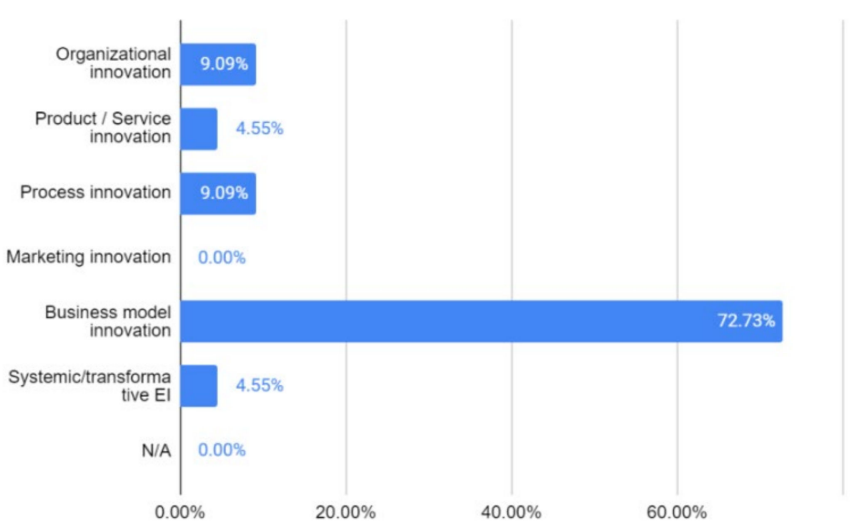

(a)

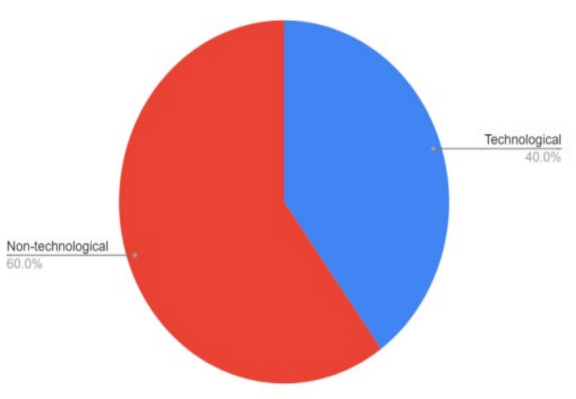

(b)

Figure 10. (a) Main types of innovation per “New Business Models" CE strategy (value chain); (b) Main mechanisms of innovation per "New Business Models" CE strategy (value chain). Source: elaborations on the corpus. 


\subsubsection{Papers Not Adhering to Specific CE Strategies}

An important set of papers (around 15\% of the sample) did not focus on any of the specific CE strategies proposed in the analytical framework (designated as N/A-Not Applicable). This set of papers provides a more general conceptual approximation to the EI and $\mathrm{CE}$ connection, without a specific topical focus. A more detailed review pointed to three distinct foci: (a) the conceptual definition/ definitional limitations of the CE concept, mentioning the importance of EI in transition to a CE [3,82,116]; (b) a specific innovation pathway, usually at a firm/business level, but only marginally linking it to the $\mathrm{CE}$, for instance focusing on how $\mathrm{CE}$ related innovations (in a broad perspective) are linked to turnover and employment growth [117], or on how important are innovation networks and collaboration in the European raw material sector [118] or even on nature-inspired innovation as an innovation strategy only very tangentially mentioning CE [119]; (c) an exploration of the interconnection between EI and CE [120] and the need to have a systemic multidimensional, multi-actor systemic innovation approach to CE [11,32,33], addressing concepts like "circular ecosystem innovation" [47,121], or the triple helix concept emphasising the importance of building synergies across different stakeholders to enhance economic and social change on a systemic scale $[122,123]$. This latter subset was the most prominent one, explaining why "Systemic/transformative EI" was so mentioned (Figure 11).

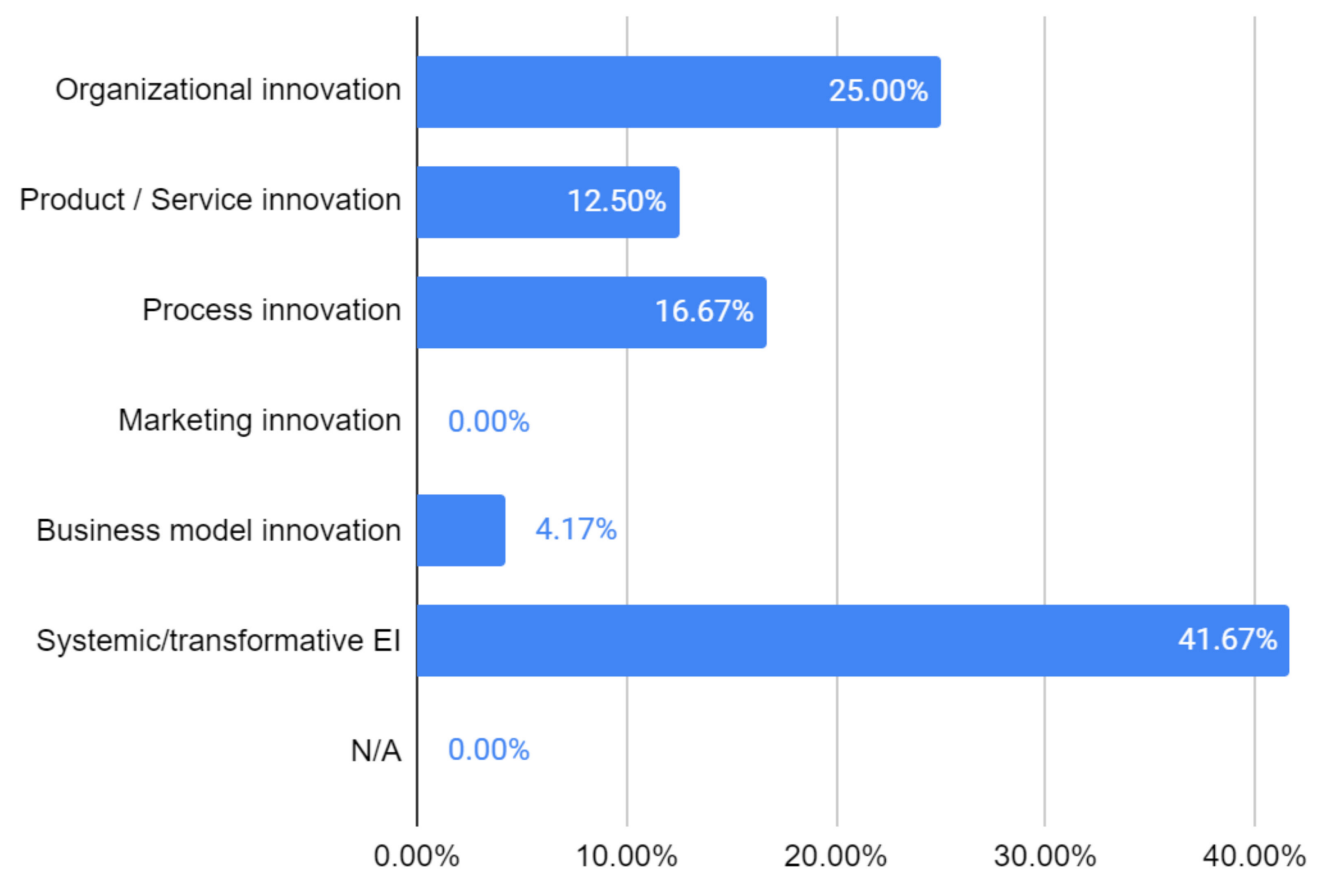

Figure 11. Main types of innovation in papers that do not focus on any of the CE strategies. Source: elaborations on the corpus.

\subsubsection{Other CE Strategies}

An important part of the sample includes a variety of CE strategies, which individually account for 1 to $10 \%$ of the sample, but that taken together adds up to one third of the sample. Papers related to "Circular Inputs" ( $8 \%$ of the sample) points to ongoing discussions concerning the definition of the bio-economy [124-126], and bio-economy business models [110]. They also cover renewable biomass products, alternatives to current petroleum-based materials, new materials (e.g., biodegradable polymers from agro-food waste residues [127], fungal mycelium [128] or applications of fish waste [89]) and their possible applications in several sectors, namely packaging, textile, leather and automotive industries just to mention a few. 
Design, circular design and specific design strategies are covered within the strategy "Design" (around $8 \%$ of the sample). This part covers aspects such as "designing out waste", implementation of design and its role in industrial products, processes and organizations [129-131]. It should also be noted that the review suggested interrelations between strategies related with "Design" and strategies focused on "Collection and disposal"which take up only $5 \%$ of the sample-especially on how extended producer responsibility or take-back systems could enable a continuous flow of products, components and material for remanufacture or recovery [132,133], as well as on strategies related with "Distribution and sales" - $3 \%$ of the sample-focused on efficient packaging design strategies and sustainable supply chains [134].

Remanufacture strategies are under-represented in the sample (5\%), and most of the contributions focus on refurbishment, while a number of those have a sectoral focus on automotive (remanufacturing) [135], construction (refurbishment) [91] and textiles [18].

"Materials sourcing" and "Manufacturing" strategies are also closely connected, representing $4 \%$ of the sample, respectively. The first set has a stronger focus on cross-sector linkages, namely concerning energy production [136,137], life cycle assessment, green procurement, taxation, as well as the role of finance in a CE [138], while the second set concentrates on energy efficiency and material productivity [101,139-141].

\section{Discussion}

The CE concept has been stressed as a socio-technical template for replacing old linear unsustainable economy by a more restorative and regenerative system. Such a transition towards economic and ecological sustainability is about structural change and is pre-conditioned on the introduction of transformative innovation. While growing research on the CE literature has highlighted the role of innovation, research exploring EI dynamics within the $C E$ is still marginal. How has $C E$ innovation research been evolving for the past ten years? The present research constituted an exploratory study focusing on systematising main trends from the published reviews relevant to understand the interaction between EI and CE.

The review highlighted that while the connections between EI and CE are stressed and the need for systemic innovation is emphasized as an enabler for the transition towards the $\mathrm{CE}$, detailed in-depth analyses of EI practices and dynamics are still largely absent in the corpus of the $\mathrm{CE}$ literature. The analysis points to the fact that most of the contributions are recent and have followed the major features of the conceptual definition of CE. Innovation is presented, in several cases also as a broad concept, without specific references to how innovation is conceptualised, what the key processes and who the stakeholders driving innovation are, or even the direction and objectives of the innovation processes in a CE. The reviewed contributions acknowledge important gaps related to how EI can contribute to the CE [123]; how to direct innovation systems to CE practices [135], as well as on how innovation and transference of knowledge on CE solutions across different regions could be deployed [97].

From a geographical point of view, the scope of the research has been largely limited to Europe and to a lesser extent the US. The review also highlighted a number of clear sectoral foci (automotive, construction, textiles, etc.) and emphasis on CE dimensions related to (1) recycling and recovering and (2) new business models. This split is also representative of the two main types of EI studied, namely technology and process innovation and softer types of organisational, value creation and cultural innovation.

New business models are generally presented as vehicular instruments of CE transition, connecting supply and demand side innovations while driving other forms of innovation linked to design, product manufacturing, logistics and reverse logistics, and end of life management and recovery. Even though contributions in the field of new business models constitute a focal theme in the CE literature, several knowledge gaps were identified in the analysed sample. Main issues pointed to the need for further conceptual 
development, in-depth assessment of practical implementation and review of challenges to implementation from an innovation perspective [3,108,115].

The review also suggests that further research is needed to better define the role of diverse stakeholders in processes related to innovation [123]. The role of consumers and retailers is largely undeveloped [112], as well as the assessment of uncertainty and risks in circular business models in areas such as financing, consumer acceptance, circular material supply and others-see, for example, [3,138]. de Jesus et al. [32] highlight limitations of adopting a narrow approach to innovation in CE and highlight the need for a "multidimensional, multi-actor systemic innovation approach". This also relates to how barriers and drivers to innovation are portrayed in CE where 'soft' factors of innovation related to business organisation, policy culture and actor networks are hampered by 'hard' barriers related to finance or business models. This creates some imbalance between lack of understanding of innovation processes and a focus on a more static vision of conventional barriers to innovation which fails to acknowledge network constellations and policy landscapes shaping innovation processes.

From the nature of the research, it is also important to emphasise that conceptual understanding of EI dynamics is mainly implicit rather than explicitly discussed, compromising opportunities to advance knowledge in the area of innovation for the CE.

Finally, the review also identifies gaps with regards to metrics and assessment frameworks for innovation. Assessment tends to be mostly qualitative (e.g., leadership), with some contributions focusing on measuring outputs of innovation such as firm performance metrics through financial revenue rather than approaches to assess innovation dynamics and processes $[3,110,118]$.

Notwithstanding, this research also has some methodological limitations. Initial searches of $C E$ and innovation resulted in a high number of contributions that were filtered out through a number of subsequent phases. The scope has been restricted to review papers to provide foundations for a meta-analysis of innovation and CE, but a broader analysis could enrich the preliminary results gathered here. Moreover, analytically, even though the CE strategies used appear suited, it still raises questions as to whether a contribution can be assigned to a specific strategy because most of them are deeply intertwined with crosscutting areas running through the different contributions. To minimise these limitations, several quality checks were deployed to validate the criteria and codification exercise's coherence, but further research could improve on the validity of the methodology.

Further research pathways should also further address the need to overcome the predominant approach of treating innovation as an afterthought (required but not discussed) and deepen the knowledge on innovation dynamics within a CE. Moreover, stronger links can be built with other emergent research streams, of which bioeconomy and open innovation are examples [142,143].

This also implies understanding to what extent innovation processes in the CE are distinctive, and require tailored approaches, with a focus on more multi-dimensional, value-network-oriented processes. Such efforts could operationalise a "circular innovation studies" research agenda, which we can canvas as an interdisciplinary area of applied and policy-relevant research that addresses the opportunities and challenges of sustained transition toward a CI through EI.

\section{Concluding Remarks}

Circularity and innovation have been attracting attention in scholarly publications. The number of papers published has increased heavily in the last five years, especially in Europe, reflecting not only the academic but also the political and economic interest in the area. Not surprisingly, the innovations related to recycling and recovery CE strategies are in the centre of the corpus, along with business-model innovations and systemic/transformative innovations. 
Notwithstanding the methodological limitations, which invite the need for careful analysis, our paper opens the debate on what we really know about innovation dynamics within a CE by synthesising major findings available in published reviews.

In light of our findings, the innovation strategies identified in our research reflect the fact that there is a strong recognition of the importance of innovations in the transition to a circular economy, at the same time underlining a significant knowledge gap on the understanding of the actual and precise interactions between EI dynamics and CE. Therefore, where should research go from here? What could possible methodological, theoretical and empirical avenues be?

For one, the conceptual understanding of EI dynamics in CE is mainly implicit rather than explicitly discussed. This fragmented knowledge, in terms of both terminology and empirical focus, stresses the importance of research streams focused on addressing innovation systematically in the CE context. This is also linked with the importance of understanding if (and which) innovation processes in the $\mathrm{CE}$ are distinctive, and require tailored approaches.

On an empirical side, we would suggest that the next generation of research should explore how pro-CE EI could be assessed. This corpus was conspicuously silent concerning $\mathrm{CE}$ innovation proxies. This would also point to other research areas, namely on how innovation systems' circularity can be assessed. Monitoring innovation systems dynamics, with a particular emphasis on their "circular" activities, could enable a glimpse on CE implementation and also support the identification of policy implications.

If some conclusions can already be gathered, it must be underlined that they are provisional and, hopefully, a stepping stone to a full-blown agenda. Above all, what seems clear is the need for more studies and analysis of further sources in order to establish "circular innovation studies" as a research programme in its own right.

Author Contributions: Conceptualization, A.d.J., M. L., T.D., F.V., S.M.; methodology, A.d.J., M. L., T.D., F.V., S.M.; validation, A.d.J., M.L., F.V.; formal analysis, A.d.J., M.L., F.V.; writing—original draft preparation, A.d.J.; writing—review and editing, A.d.J., M.L., T.D., F.V., S.M. All authors have read and agreed to the published version of the manuscript.

Funding: This research received no external funding.

Acknowledgments: Support by FCT (Fundação para a Ciência e a Tecnologia), Portugal is gratefully acknowledged. We would like to acknowledge Business Research Unit (BRU-IUL) and UECE (Research Unit on Complexity and Economics). BRU-IUL benefited from Grant UID/GES/00315/2013 and is part of the project PTDC/EGE-ECO/30690/2017. UECE is financially supported by FCT (Fundação para a Ciência e a Tecnologia), Portugal. Also acknowledgments to CENSE-Center for Environmental and Sustainability. CENSE research is financed by Fundação para a Ciência e a Tecnologia (projects UIDB/04085/2020 and UIDP/04085/2020). Any remaining errors remain our own.

Conflicts of Interest: The authors declare no conflict of interest.
Abbreviations
CE Circular Economy
EI Eco-innovation
WoS Web of Science
N/A Not Applicable

\section{References}

1. $\quad$ Rockström, J.; Steffen, W.; Noone, K.; Persson, Å.; Chapin, F.S.; Lambin, E.F; Lenton, T.M.; Scheffer, M.; Folke, C.; Schellnhuber, H.J.; et al. A Safe Operating Space for Humanity. Nature 2009, 461, 472-475. [CrossRef]

2. Woetzel, J; Sellschop, R.; Chui, M.; Ramaswamy, S.; Nyquist, S.; Robinson, H.; Roelofsen, O.; Rogers, M.; Ross, R. How Technology Is Reshaping Supply and Demand for Natural Resources; McKinsey \& Company, 2017.

3. de Angelis, R. Circular Economy: Laying the Foundations for Conceptual and Theoretical Development in Management Studies. Manag. Decis. 2021, 59, 1209-1227. [CrossRef] 
4. Geissdoerfer, M.; Savaget, P.; Bocken, N.M.P.; Hultink, E.J. The Circular Economy-A New Sustainability Paradigm? J. Clean. Prod. 2017, 143, 757-768. [CrossRef]

5. Korhonen, J.; Honkasalo, A.; Seppälä, J. Circular Economy: The Concept and Its Limitations. Ecol. Econ. 2018, 143, 37-46. [CrossRef]

6. Ellen MacArthur Foundation. Foundation Delivering the Circular Economy. A Toolkit for Policy Makers; Ellen MacArthur Foundation: Cowes, United Kingdom, 2015.

7. Centobelli, P.; Cerchione, R.; Chiaroni, D.; Vecchio, P.D.; Urbinati, A. Designing Business Models in Circular Economy: A Systematic Literature Review and Research Agenda. Bus. Strategy Environ. 2020, 29, 1734-1749. [CrossRef]

8. Denise, R.; Vermeulen, W.; Witjes, S. The circular economy: New or Refurbished as CE 3.0? — Exploring Controversies in the Conceptualization of the Circular Economy through a Focus on History and Resource Value Retention Options. Resour. Conserv. Recycl. 2018, 135, 246-264.

9. Kirchherr, J.; Reike, D.; Hekkert, M. Conceptualizing the Circular Economy: An Analysis of 114 Definitions. Resour. Conserv. Recycl. 2017, 127, 221-232. [CrossRef]

10. Sauvé, S.; Bernard, S.; Sloan, P. Environmental Sciences, Sustainable Development and Circular Economy: Alternative Concepts for Trans-Disciplinary Research. Environ. Dev. 2016, 17, 48-56. [CrossRef]

11. de Jesus, A.; Antunes, P.; Santos, R.; Mendonça, S. Eco-Innovation in the Transition to a Circular Economy: An Analytical Literature Review. J. Clean. Prod. 2018, 172, 2999-3018. [CrossRef]

12. Kočí, J.; Fořt, J.; Černý, R. Energy Efficiency of Latent Heat Storage Systems in Residential Buildings: Coupled Effects of Wall Assembly and Climatic Conditions. Renewable and Sustainable Energy Rev. 2020, 132, 110097. [CrossRef]

13. Hamam, M.; Chinnici, G.; Di Vita, G.; Pappalardo, G.; Pecorino, B.; Maesano, G.; D'Amico, M. Circular Economy Models in Agro-Food Systems: A Review. Sustainability 2021, 13, 3453. [CrossRef]

14. Piribauer, B.; Bartl, A. Textile Recycling Processes, State of the Art and Current Developments: A Mini Review. Waste Manag. Res. 2019, 37, 112-119. [CrossRef] [PubMed]

15. Calleja, D. Why the "New Plastics Economy" Must Be a Circular Economy. Field Actions Sci. Rep. 2019, $2019,22-27$.

16. Gong, Y.; Putnam, E.; You, W.; Zhao, C. Investigation into Circular Economy of Plastics: The Case of the UK Fast Moving Consumer Goods Industry. J. Clean. Prod. 2020, 244, 118941. [CrossRef]

17. Mishra, S.; Jain, S.; Malhotra, G. The Anatomy of Circular Economy Transition in the Fashion Industry. Soc. Responsib. J. 2021, 17, 524-542. [CrossRef]

18. Shirvanimoghaddam, K.; Motamed, B.; Ramakrishna, S.; Naebe, M. Death by Waste: Fashion and Textile Circular Economy Case. Sci. Total. Environ. 2020, 718, 137317. [CrossRef]

19. Althaf, S.; Babbitt, C.W.; Chen, R. The Evolution of Consumer Electronic Waste in the United States. J. Ind. Ecol. 2021, 25, 693-706. [CrossRef]

20. Althaf, S.; Babbitt, C.W.; Chen, R. Forecasting Electronic Waste Flows for Effective Circular Economy Planning. Resour. Conserv. Recycl. 2019, 151, 104362. [CrossRef]

21. Álvarez-de-los-Mozos, E.; Rentería-Bilbao, A.; Díaz-Martín, F. WEEE Recycling and Circular Economy Assisted by Collaborative Robots. Appl. Sci. 2020, 10, 4800. [CrossRef]

22. Aschemann-Witzel, J.; Peschel, A.O. How Circular Will You Eat? The Sustainability Challenge in Food and Consumer Reaction to Either Waste-to-Value or yet Underused Novel Ingredients in Food. Food Qual. Prefer. 2019, 77, 15-20. [CrossRef]

23. Fernandez-Mena, H.; MacDonald, G.K.; Pellerin, S.; Nesme, T. Co-Benefits and Trade-Offs from Agro-Food System Redesign for Circularity: A Case Study with the FAN Agent-Based Model. Front. Sustain. Food Syst. 2020, 4, 41. [CrossRef]

24. Calabrese, A.; Castaldi, C.; Forte, G.; Levialdi, N.G. Sustainability-Oriented Service Innovation: An Emerging Research Field. J. Clean. Prod. 2018, 193, 533-548. [CrossRef]

25. Fernandes, S.D.C.; Pigosso, D.C.A.; McAloone, T.C.; Rozenfeld, H. Towards Product-Service System Oriented to Circular Economy: A Systematic Review of Value Proposition Design Approaches. J. Clean. Prod. 2020, 257, 120507. [CrossRef]

26. Skene, K.R. Circles, Spirals, Pyramids and Cubes: Why the Circular Economy Cannot Work. Sustain. Sci. 2017, 13, 1-14. [CrossRef]

27. Kalmykova, Y.; Sadagopan, M.; Rosado, L. Circular Economy-From Review of Theories and Practices to Development of Implementation Tools. Resour. Conserv. Recycl. 2018, 135, 190-201. [CrossRef]

28. Circle Economy. The Circularity Gap Report 2021; Platform for Accelerating the Circular Economy (PACE): Amsterdam, The Netherlands, 2021.

29. Elzen, B.; Geels, F.W.; Green, K. System Innovation and the Transition to Sustainability: Theory, Evidence and Policy; Edward Elgar Publishing: Cheltenham, UK; Northampton, MA, USA, 2004; ISBN 9781845423421.

30. Geels, F.W.; Hekkert, M.P.; Jacobsson, S. The Dynamics of Sustainable Innovation Journeys. Technol. Anal. Strateg. Manag. 2008, 20, 521-536. [CrossRef]

31. European Commission. Communication from the commission to the european parliament, the council, the european economic and social committee and the committee of the regions - Closing the Loop-An EU Action Plan for the Circular Economy; COM(2015) 614 final; European Commission: Brussels, Belgium, 2015.

32. de Jesus, A.; Antunes, P.; Santos, R.; Mendonça, S. Eco-Innovation Pathways to a Circular Economy: Envisioning Priorities through a Delphi Approach. J. Clean. Prod. 2019, 228, 1494-1513. [CrossRef] 
33. de Jesus, A.; Mendonça, S. Lost in Transition? Drivers and Barriers in the Eco-Innovation Road to the Circular Economy. Ecol. Econ. 2018, 145, 75-89. [CrossRef]

34. Carrión-Flores, C.E.; Innes, R. Environmental Innovation and Environmental Performance. J. Environ. Econ. Manag. 2010, 59, 27-42. [CrossRef]

35. van den Bergh, J.C.J.M.; Truffer, B.; Kallis, G. Environmental Innovation and Societal Transitions: Introduction and Overview. Environ. Innov. Soc. Transit. 2011, 1, 1-23. [CrossRef]

36. Weber, K.M.; Hemmelskamp, J. Towards Environmental Innovation Systems; Springer Science \& Business Media: Berlin/Heidelberg, Germany, 2005; ISBN 9783540223221.

37. Boons, F.; Montalvo, C.; Quist, J.; Wagner, M. Sustainable Innovation, Business Models and Economic Performance: An Overview. J. Clean. Prod. 2013, 45, 1-8. [CrossRef]

38. Chen, Y.-S.; Lai, S.-B.; Wen, C.-T. The Influence of Green Innovation Performance on Corporate Advantage in Taiwan. J. Bus. Ethics 2006, 67, 331-339. [CrossRef]

39. Cuerva, M.C.; Triguero-Cano, Á.; Córcoles, D. Drivers of Green and Non-Green Innovation: Empirical Evidence in Low-Tech SMEs. J. Clean. Prod. 2014, 68, 104-113. [CrossRef]

40. Li, L.; Msaad, H.; Sun, H.; Tan, M.X.; Lu, Y.; Lau, A.K.W. Green Innovation and Business Sustainability: New Evidence from Energy Intensive Industry in China. Int. J. Environ. Res. Public Health 2020, 17, 1-18. [CrossRef] [PubMed]

41. Horbach, J. Determinants of Environmental Innovation-New Evidence from German Panel Data Sources. Res. Policy 2008, $37,163-173$. [CrossRef]

42. Carrillo-Hermosilla, J.; del Río, P.; Könnölä, T. Diversity of Eco-Innovations: Reflections from Selected Case Studies. J. Clean. Prod. 2010, 18, 1073-1083. [CrossRef]

43. Hofstra, N.; Huisingh, D. Eco-Innovations Characterized: A Taxonomic Classification of Relationships between Humans and Nature. J. Clean. Prod. 2014, 66, 459-468. [CrossRef]

44. Jo, J.-H.; Roh, T.W.; Kim, S.; Youn, Y.-C.; Park, M.S.; Han, K.J.; Jang, E.K. Eco-Innovation for Sustainability: Evidence from 49 Countries in Asia and Europe. Sustainability 2015, 7, 16820-16835. [CrossRef]

45. Martin, B.R. Twenty Challenges for Innovation Studies. Sci. Public Policy 2016, 43, 432-450. [CrossRef]

46. Schot, J.; Kanger, L. Deep Transitions: Emergence, Acceleration, Stabilization and Directionality. Res. Policy 2018, 47, 1045-1059. [CrossRef]

47. Konietzko, J.; Bocken, N.; Hultink, E.J. Circular Ecosystem Innovation: An Initial Set of Principles. J. Clean. Prod. 2020, $253,119942$. [CrossRef]

48. Brewerton, P.M.; Millward, L. Organizational Research Methods: A Guide for Students and Researchers, 1st ed.; SAGE Publications: London, UK; Thousand Oaks, CA, USA, 2001; ISBN 9780761971016.

49. Denyer, D.; Tranfield, D. Producing a systematic review. In The Sage Handbook of Organizational Research Methods; Sage Publications Ltd: Thousand Oaks, CA, USA, 2009; pp. 671-689. ISBN 9781412931182.

50. Tranfield, D.; Denyer, D.; Smart, P. Towards a Methodology for Developing Evidence-Informed Management Knowledge by Means of Systematic Review. Br. J. Manag. 2003, 14, 207-222. [CrossRef]

51. Merli, R.; Preziosi, M.; Acampora, A. How Do Scholars Approach the Circular Economy? A Systematic Literature Review. J. Clean. Prod. 2018, 178, 703-722. [CrossRef]

52. Xavier, A.F.; Naveiro, R.M.; Aoussat, A.; Reyes, T. Systematic Literature Review of Eco-Innovation Models: Opportunities and Recommendations for Future Research. J. Clean. Prod. 2017, 149, 1278-1302. [CrossRef]

53. Akhimien, N.G.; Latif, E.; Hou, S.S. Application of Circular Economy Principles in Buildings: A Systematic Review. J. Build. Eng. 2021, 38, 102041. [CrossRef]

54. Bocken, N.; Strupeit, L.; Whalen, K.; Nußholz, J. A Review and Evaluation of Circular Business Model Innovation Tools. Sustainability 2019, 11, 2210. [CrossRef]

55. de Oliveira, M.M.; Lago, A.; Dal'Magro, G.P. Food Loss and Waste in the Context of the Circular Economy: A Systematic Review. J. Clean. Prod. 2021, 294, 126284. [CrossRef]

56. Rosa, P.; Sassanelli, C.; Urbinati, A.; Chiaroni, D.; Terzi, S. Assessing Relations between Circular Economy and Industry 4.0: A Systematic Literature Review. Int. J. Prod. Res. 2020, 58, 1662-1687. [CrossRef]

57. Padilla-Rivera, A.; Russo-Garrido, S.; Merveille, N. Addressing the Social Aspects of a Circular Economy: A Systematic Literature Review. Sustainability 2020, 12, 7912. [CrossRef]

58. de Pascale, A.; Arbolino, R.; Szopik-Depczyńska, K.; Limosani, M.; Ioppolo, G. A Systematic Review for Measuring Circular Economy: The 61 Indicators. J. Clean. Prod. 2021, 281, 124942. [CrossRef]

59. Martinho, V.J.P.D. Insights into Circular Economy Indicators: Emphasizing Dimensions of Sustainability. Environ. Sustain. Indic. 2021, 10, 100119. [CrossRef]

60. Sassanelli, C.; Rosa, P.; Rocca, R.; Terzi, S. Circular Economy Performance Assessment Methods: A Systematic Literature Review. J. Clean. Prod. 2019, 229, 440-453. [CrossRef]

61. Edwards-Schachter, M. The Nature and Variety of Innovation. Int. J. Innov. Stud. 2018, 2, 65-79. [CrossRef]

62. Organisation for Economic Co-operation and Development. The Measurement of Scientific and Technological Activities—Oslo Manual; Guidelines for Collecting and Interpreting Innovation Data, 3rd ed; OECD Publishing: Paris, France, 2005; ISBN 9789264013100. 
63. Colvin, J.; Blackmore, C.; Chimbuya, S.; Collins, K.; Dent, M.; Goss, J.; Ison, R.; Roggero, P.P.; Seddaiu, G. In Search of Systemic Innovation for Sustainable Development: A Design Praxis Emerging from a Decade of Social Learning Inquiry. Res. Policy 2014, 43, 760-771. [CrossRef]

64. Gaziulusoy, A.İ; Boyle, C.; McDowall, R. System Innovation for Sustainability: A Systemic Double-Flow Scenario Method for Companies. J. Clean. Prod. 2013, 45, 104-116. [CrossRef]

65. Boons, F.; Lüdeke-Freund, F. Business Models for Sustainable Innovation: State-of-the-Art and Steps towards a Research Agenda. J. Clean. Prod. 2013, 45, 9-19. [CrossRef]

66. Geissdoerfer, M.; Vladimirova, D.; Evans, S. Sustainable Business Model Innovation: A Review. J. Clean. Prod. 2018, 198, 401-416. [CrossRef]

67. OECD. Oslo Manual 2018: Guidelines for Collecting, Reporting and Using Data on Innovation, 4th ed.; OECD: Paris, France, 2018.

68. Zhu, J.; Liu, W. A Tale of Two Databases: The Use of Web of Science and Scopus in Academic Papers. Scientometrics 2020, 123, 321-335. [CrossRef]

69. Falagas, M.E.; Pitsouni, E.I.; Malietzis, G.A.; Pappas, G. Comparison of PubMed, Scopus, Web of Science, and Google Scholar: Strengths and Weaknesses. FASEB J. 2008, 22, 338-342. [CrossRef] [PubMed]

70. Chappin, E.J.L.; Ligtvoet, A. Transition and Transformation: A Bibliometric Analysis of Two Scientific Networks Researching Socio-Technical Change. Renew. Sustain. Energy Rev. 2014, 30, 715-723. [CrossRef]

71. Chadegani, A.A.; Salehi, H.; Yunus, M.; Farhadi, H.; Fooladi, M.; Farhadi, M.; Ebrahim, A.E. Comparison between Two Main Academic Literature Collections: Web of Science and Scopus Databases; Social Science Research Network: Rochester, NY, USA, 2013.

72. Haddaway, N.R.; Grames, E.M.; Boyes, D.H.; Saunders, M.E.; Taylor, N.G. What Evidence Exists on Conservation Actions to Conserve Insects? A Protocol for a Systematic Map of Literature Reviews. Environ. Evid. 2020, 9, 30. [CrossRef]

73. Smith, V.; Devane, D.; Begley, C.M.; Clarke, M. Methodology in Conducting a Systematic Review of Systematic Reviews of Healthcare Interventions. BMC Med Res. Methodol. 2011, 11, 15. [CrossRef]

74. Becker, L.; Oxman, A. Cochrane Handbook for Systematic Reviews of Interventions; Higgins, J.P., Green, S., Eds.; The Cochrane Collaboration: Oxford, UK, 2009.

75. Camón Luis, E.; Celma, D. Circular Economy. A Review and Bibliometric Analysis. Sustainability 2020, 12, 6381. [CrossRef]

76. Palmatier, R.W.; Houston, M.B.; Hulland, J. Review Articles: Purpose, Process, and Structure. J. Acad. Mark. Sci. 2018, 46, 1-5. [CrossRef]

77. Van Dinter, R.; Tekinerdogan, B.; Catal, C. Automation of systematic literature reviews: A systematic literature review. Inf. Sotfw. Technol. 2021, 136, 106589. [CrossRef]

78. Buchheim, L.; Krieger, A.; Arndt, S. Innovation Types in Public Sector Organizations: A Systematic Review of the Literature. Manag. Rev. Q. 2020, 70, 509-533. [CrossRef]

79. Bown, M.J.; Sutton, A.J. Quality Control in Systematic Reviews and Meta-Analyses. Eur. J. Vasc. Endovasc. Surg. 2010, 40, 669-677. [CrossRef]

80. Haddaway, N.R.; Bernes, C.; Jonsson, B.G.; Hedlund, K. The benefits of systematic mapping to evidence-based environmental management. Ambio 45, 613-620 (2016). Ambio 2016, 45, 613-620. [CrossRef]

81. James, K.L.; Randall, N.P.; Haddaway, N.R. A Methodology for Systematic Mapping in Environmental Sciences. Environ. Evid. 2016, 5, 7. [CrossRef]

82. Prieto-Sandoval, V.; Jaca, C.; Ormazabal, M. Towards a Consensus on the Circular Economy. J. Clean. Prod. 2018, 179, 605-615. [CrossRef]

83. Nascimento, D.L.M.; Alencastro, V.; Quelhas, O.L.G.; Caiado, R.G.G.; Garza-Reyes, J.A.; Lona, L.R.; Tortorella, G. Exploring Industry 4.0 Technologies to Enable Circular Economy Practices in a Manufacturing Context: A Business Model Proposal. J. Manuf. Technol. Manag. 2019, 30, 607-627. [CrossRef]

84. Rizos, V.; Behrens, A.; Van der Gaast, W.; Hofman, E.; Ioannou, A.; Kafyeke, T.; Flamos, A.; Rinaldi, R.; Papadelis, S.; HirschnitzGarbers, M.; et al. Implementation of Circular Economy Business Models by Small and Medium-Sized Enterprises (SMEs): Barriers and Enablers. Sustainability 2016, 8, 1212. [CrossRef]

85. Tijssen, R.J.W.; Visser, M.S.; van Leeuwen, T.N. Benchmarking International Scientific Excellence: Are Highly Cited Research Papers an Appropriate Frame of Reference? Scientometrics 2002, 54, 381-397. [CrossRef]

86. Shapira, Z. "I've Got a Theory Paper-Do You?": Conceptual, Empirical, and Theoretical Contributions to Knowledge in the Organizational Sciences. Organ. Sci. 2011, 22, 1312-1321. [CrossRef]

87. Amato, A.; Becci, A.; Beolchini, F. Citric Acid Bioproduction: The Technological Innovation Change. Crit. Rev. Biotechnol. 2020, 40, 199-212. [CrossRef]

88. Carillo, P.; Amelia, L.D.; Aversana, E.D.; Faiella, D.; Cacace, D.; Giuliano, B.; Morrone, B. Eco-Friendly Use of Tomato Processing Residues for Lactic Acid Production in Campania. Chem. Eng. Trans. 2018, 64, 223-228. [CrossRef]

89. Maschmeyer, T.; Luque, R.; Selva, M. Upgrading of Marine (Fish and Crustaceans) Biowaste for High Added-Value Molecules and Bio(Nano)-Materials. Chem. Soc. Rev. 2020, 49, 4527-4563. [CrossRef] [PubMed]

90. Dewick, P.; Maytorena-Sanchez, E.; Winch, G. Regulation and Regenerative Eco-Innovation: The Case of Extracted Materials in the UK. Ecol. Econ. 2019, 160, 38-51. [CrossRef]

91. Hopkinson, P.; Chen, H.-M.; Zhou, K.; Wang, Y.; Lam, D. Recovery and Reuse of Structural Products from End-of-Life Buildings. Proc. Inst. Civ. Eng.-Eng. Sustain. 2019, 172, 119-128. [CrossRef] 
92. Rocchetti, L.; Amato, A.; Beolchini, F. Printed Circuit Board Recycling: A Patent Review. J. Clean. Prod. 2018, 178, 814-832. [CrossRef]

93. Sarc, R.; Curtis, A.; Kandlbauer, L.; Khodier, K.; Lorber, K.E.; Pomberger, R. Digitalisation and Intelligent Robotics in Value Chain of Circular Economy Oriented Waste Management-A Review. Waste Manag. 2019, 95, 476-492. [CrossRef]

94. Ubaldini, S.; Guglietta, D.; Trapasso, F.; Carloni, S.; Passeri, D.; Scotti, A. Treatment of Secondary Raw Materials by Innovative Processes. Chem. J. Mold. 2019, 14, 32-46. [CrossRef]

95. Akyol, Ç.; Foglia, A.; Ozbayram, E.G.; Frison, N.; Katsou, E.; Eusebi, A.L.; Fatone, F. Validated Innovative Approaches for Energy-Efficient Resource Recovery and Re-Use from Municipal Wastewater: From Anaerobic Treatment Systems to a Biorefinery Concept. Crit. Rev. Environ. Sci. Technol. 2020, 50, 869-902. [CrossRef]

96. Blankesteijn, M.; Bossink, B. Assessing the Legitimacy of Technological Innovation in the Public Sphere: Recovering Raw Materials from Waste Water. Sustainability 2020, 12, 9408. [CrossRef]

97. Dąbrowski, M.; Varjú, V.; Amenta, L. Transferring Circular Economy Solutions across Differentiated Territories: Understanding and Overcoming the Barriers for Knowledge Transfer. Urban Plan. 2019, 4, 52-62. [CrossRef]

98. Robles, Á.; Aguado, D.; Barat, R.; Borrás, L.; Bouzas, A.; Giménez, J.B.; Martí, N.; Ribes, J.; Ruano, M.V.; Serralta, J.; et al. New Frontiers from Removal to Recycling of Nitrogen and Phosphorus from Wastewater in the Circular Economy. Bioresour. Technol. 2020, 300, 122673. [CrossRef] [PubMed]

99. Branca, T.A.; Colla, V.; Algermissen, D.; Granbom, H.; Martini, U.; Morillon, A.; Pietruck, R.; Rosendahl, S. Reuse and Recycling of By-Products in the Steel Sector: Recent Achievements Paving the Way to Circular Economy and Industrial Symbiosis in Europe. Metals 2020, 10, 345. [CrossRef]

100. Patricio, J.; Axelsson, L.; Blomé, S.; Rosado, L. Enabling Industrial Symbiosis Collaborations between SMEs from a Regional Perspective. J. Clean. Prod. 2018, 202, 1120-1130. [CrossRef]

101. Naims, H. Economic Aspirations Connected to Innovations in Carbon Capture and Utilization Value Chains. J. Ind. Ecol. 2020, 24, 1126-1139. [CrossRef]

102. Azcárate-Aguerre, J.F.; Den Heijer, A.; Klein, T. Integrated Faades as a Product-Service System -Business Process Innovation to Accelerate Integral Product Implementation. J. Facade Des. Eng. 2018, 6, 41-56. [CrossRef]

103. Guzzo, D.; Trevisan, A.H.; Echeveste, M.; Costa, J.M.H. Circular Innovation Framework: Verifying Conceptual to Practical Decisions in Sustainability-Oriented Product-Service System Cases. Sustainability 2019, 11, 3248. [CrossRef]

104. Sposato, P.; Preka, R.; Cappellaro, F.; Cutaia, L. Sharing Economy and Circular Economy. How Technology and Collaborative Consumption Innovations Boost Closing the Loop Strategies. Environ. Eng. Manag. J. 2017, 16, 1797-1806. [CrossRef]

105. Geissdoerfer, M.; Pieroni, M.P.P.; Pigosso, D.C.A.; Soufani, K. Circular Business Models: A Review. J. Clean. Prod. 2020, 277, 123741. [CrossRef]

106. Müller, M.; Vorraber, W.; Slany, W. Open Principles in New Business Models for Information Systems. J. Open Innov. Technol. Mark. Complex. 2019, 5, 6. [CrossRef]

107. Nosratabadi, S.; Mosavi, A.; Shamshirband, S.; Zavadskas, E.K.; Rakotonirainy, A.; Chau, K.W. Sustainable Business Models: A Review. Sustainability 2019, 11, 1663. [CrossRef]

108. Nußholz, J.L.K. Circular Business Models: Defining a Concept and Framing an Emerging Research Field. Sustainability 2017, 9, 1810. [CrossRef]

109. Todeschini, B.V.; Cortimiglia, M.N.; Callegaro-de-Menezes, D.; Ghezzi, A. Innovative and Sustainable Business Models in the Fashion Industry: Entrepreneurial Drivers, Opportunities, and Challenges. Bus. Horiz. 2017, 60, 759-770. [CrossRef]

110. Reim, W.; Parida, V.; Sjödin, D.R. Circular Business Models for the Bio-Economy: A Review and New Directions for Future Research. Sustainability 2019, 11, 2558. [CrossRef]

111. Cristoni, N.; Tonelli, M. Perceptions of Firms Participating in a Circular Economy. Eur. J. Sustain. Dev. 2018, 7, 105. [CrossRef]

112. Borrello, M.; Pascucci, S.; Caracciolo, F.; Lombardi, A.; Cembalo, L. Consumers Are Willing to Participate in Circular Business Models: A Practice Theory Perspective to Food Provisioning. J. Clean. Prod. 2020, 259, 121013. [CrossRef]

113. Hankammer, S.; Brenk, S.; Fabry, H.; Nordemann, A.; Piller, F.T. Towards Circular Business Models: Identifying Consumer Needs Based on the Jobs-to-Be-Done Theory. J. Clean. Prod. 2019, 231, 341-358. [CrossRef]

114. Jakhar, S.K.; Mangla, S.K.; Luthra, S.; Kusi-Sarpong, S. When Stakeholder Pressure Drives the Circular Economy: Measuring the Mediating Role of Innovation Capabilities. Manag. Decis. 2019, 57, 904-920. [CrossRef]

115. Sattari, S.; Wessman, A.; Borders, L. Business Model Innovation for Sustainability: An Investigation of Consumers' Willingness to Adopt Product-Service Systems. J. Glob. Sch. Mark. Sci. 2020, 30, 274-290. [CrossRef]

116. Zalewski, R.I. Circular Economy as a Management Model in the Paradigm of Sustainable Development. Management 2018, 22, 217-233. [CrossRef]

117. Horbach, J.; Rammer, C. Circular Economy Innovations, Growth and Employment at the Firm Level: Empirical Evidence from Germany. J. Ind. Ecol. 2020, 24, 615-625. [CrossRef]

118. Smol, M.; Kulczycka, J. Towards Innovations Development in the European Raw Material Sector by Evolution of the Knowledge Triangle. Resour. Policy 2019, 62, 453-462. [CrossRef]

119. Mead, T.; Jeanrenaud, S.; Bessant, J. Factors Influencing the Application of Nature as Inspiration for Sustainability-Oriented Innovation in Multinational Corporations. Bus. Strategy Environ. 2020, 29, 3162-3173. [CrossRef] 
120. Colombo, L.A.; Pansera, M.; Owen, R. The Discourse of Eco-Innovation in the European Union: An Analysis of the Eco-Innovation Action Plan and Horizon 2020. J. Clean. Prod. 2019, 214, 653-665. [CrossRef]

121. Konietzko, J.; Bocken, N.; Hultink, E.J. A Tool to Analyze, Ideate and Develop Circular Innovation Ecosystems. Sustainability 2020, 12. [CrossRef]

122. Barrie, J.; Zawdie, G.; João, E. Leveraging Triple Helix and System Intermediaries to Enhance Effectiveness of Protected Spaces and Strategic Niche Management for Transitioning to Circular Economy. Int. J. Technol. Manag. Sustain. Dev. 2017, $16,25-47$. [CrossRef]

123. Durán-Romero, G.; López, A.M.; Beliaeva, T.; Ferasso, M.; Garonne, C.; Jones, P. Bridging the Gap between Circular Economy and Climate Change Mitigation Policies through Eco-Innovations and Quintuple Helix Model. Technol. Forecast. Soc. Chang. 2020, 160, 120246. [CrossRef]

124. Birtchnell, T.; Urry, J. 3D, SF and the Future. Futures 2013, 50, 25-34. [CrossRef]

125. Bröring, S.; Laibach, N.; Wustmans, M. Innovation Types in the Bioeconomy. J. Clean. Prod. 2020, 266, 121939. [CrossRef]

126. Hedeler, B.; Lettner, M.; Stern, T.; Schwarzbauer, P.; Hesser, F. Strategic Decisions on Knowledge Development and Diffusion at Pilot and Demonstration Projects: An Empirical Mapping of Actors, Projects and Strategies in the Case of Circular Forest Bioeconomy. For. Policy Econ. 2020, 110, 102027. [CrossRef]

127. Guillard, V.; Gaucel, S.; Fornaciari, C.; Angellier-Coussy, H.; Buche, P.; Gontard, N. The Next Generation of Sustainable Food Packaging to Preserve Our Environment in a Circular Economy Context. Front. Nutr. 2018, 5, 121. [CrossRef]

128. Cerimi, K.; Akkaya, K.C.; Pohl, C.; Schmidt, B.; Neubauer, P. Fungi as Source for New Bio-Based Materials: A Patent Review. Fungal Biol. Biotechnol. 2019, 6, 17. [CrossRef]

129. Baldassarre, B.; Keskin, D.; Diehl, J.C.; Bocken, N.; Calabretta, G. Implementing Sustainable Design Theory in Business Practice: A Call to Action. J. Clean. Prod. 2020, 273, 123113. [CrossRef]

130. Lesakova, L. Small and Medium Enterprises and Eco-Innovations: Empirical Study of Slovak SME's. Mark. Manag. Innov. 2019, 3, 89-97. [CrossRef]

131. Whicher, A.; Harris, C.; Beverley, K.; Swiatek, P. Design for Circular Economy: Developing an Action Plan for Scotland. J. Clean. Prod. 2018, 172, 3237-3248. [CrossRef]

132. Cottafava, D.; Riccardo, L.E.; D'Affuso, C. From Flow to Stock. New Circular Business Models for Integrated Systems: A Case Study on Reusable Plastic Cups. Procedia Environ. Sci. Eng. Manag. 2019, 6, 81-94.

133. Kuo, T.-C.; Smith, S. A Systematic Review of Technologies Involving Eco-Innovation for Enterprises Moving towards Sustainability. J. Clean. Prod. 2018, 192, 207-220. [CrossRef]

134. Tebaldi, L.; Bigliardi, B.; Bottani, E. Sustainable Supply Chain and Innovation: A Review of the Recent Literature. Sustainability 2018, 10, 3946. [CrossRef]

135. Maldonado-Guzmán, G.; Garza-Reyes, J.A.; Pinzón-Castro, Y. Eco-Innovation and the Circular Economy in the Automotive Industry. Benchmarking Int. J. 2020, 28, 621-635. [CrossRef]

136. Chauvy, R.; de Weireld, G. $\mathrm{CO}_{2}$ Utilization Technologies in Europe: A Short Review. Energy Technol. 2020, 8, 2000627. [CrossRef]

137. Vokoun, M.; Jílková, J. Eco-Innovation Activities in the Czech Economy 2008-2014: Impact of the Eco-Innovative Approach to the Profit Stream and Differences in Urban and Rural Enterprises. Economies 2020, 8, 3. [CrossRef]

138. Bui, T.D.; Ali, M.H.; Tsai, F.M.; Iranmanesh, M.; Tseng, M.-L.; Lim, M.K. Challenges and Trends in Sustainable Corporate Finance: A Bibliometric Systematic Review. J. Risk Financ. Manag. 2020, 13, 264. [CrossRef]

139. Cioffi, R.; Travaglioni, M.; Piscitelli, G.; Petrillo, A.; Parmentola, A. Smart Manufacturing Systems and Applied Industrial Technologies for a Sustainable Industry: A Systematic Literature Review. Appl. Sci. 2020, 10, 2897. [CrossRef]

140. Hojnik, J.; Ruzzier, M.; Manolova, T. Eco-Innovation and Firm Efficiency: Empirical Evidence from Slovenia. Foresight STI Gov. 2017, 11, 103-111. [CrossRef]

141. Kiefer, C.P.; Carrillo-Hermosilla, J.; Del Río, P. Building a Taxonomy of Eco-Innovation Types in Firms. A Quantitative Perspective. Resour. Conserv. Recycl. 2019, 145, 339-348. [CrossRef]

142. Leitão, J.; Pereira, D.; Brito, S.D. Inbound and Outbound Practices of Open Innovation and Eco-Innovation: Contrasting Bioeconomy and Non-Bioeconomy Firms. J. Open Innov. Technol. Mark. Complex. 2020, 6, 145. [CrossRef]

143. Santos, A.B.; Bogers, M.; Norm, M.T.; Mendonça, S. Public policy for open innovation: Opening up to a new domain for research and practice. Technol. Forecast. Soc. Chang. 2021, 169, 1-4. [CrossRef] 